\title{
Shoring Up Sappho
}

\section{P.Oxy. 2288 and Ancient Reinforcements of Bookrolls}

\author{
Mark de Kreij \\ Greek and Latin Language and Culture, Radboud University Nijmegen \\ m.dekreij@let.ru.nl \\ Daniela Colomo \\ The Oxyrhynchus Papyri, University of Oxford \\ daniela.colomo@classics.ox.ac.uk
}

\author{
Andrew Lui \\ Department of Materials, University of Oxford \\ andrew.lui@materials.ox.ac.uk
}

Received April 2019 | Accepted August 2019

\begin{abstract}
P.Oxy. 2288, a 2nd-century fragment containing Sappho's Ode to Aphrodite, has an underlying layer of papyrus that has intrigued scholars for decades. X-ray tomography of the papyrus and a study of the ink under the scanning electron microscope allow us to establish that the underlying layer most likely does not contain more of Sappho's poetry. Rather, it appears that P.Oxy. 2288 is what remains of a much-used roll of Sappho book 1, reinforced at its beginning. In order to put this case in its historical context, the second part of the article contains a new examination of the literary, documentary, and papyrological evidence for ancient repairs and reinforcements of bookrolls.
\end{abstract}

\section{Keywords}

Sappho - P.Oxy. 2288 - Graeco-Roman Egypt - papyrology - ancient book repairs 
P.Oxy. 2288 is the only papyrological witness for Sappho fr. 1, the most widely quoted poem by the Lesbian poets in antiquity, and by far Sappho's best-known work. Lobel, the first editor of 2288 , keeps his edition brief, with only a few palaeographical notes on line 19, and limited commentary. Lobel was perhaps so disappointed that the papyrus did not clarify the vexing difficulty of line 19 that he did not see any further value to the small fragment. The first edition passes over a major papyrological peculiarity: the strip of papyrus consists of two complete layers, and where the bottom layer is visible, some ink may be seen (see fig. 1).

Turner, a few decades later, does mention the underlying layer, and regards it likely that it contained the same handwriting and therefore more of the same roll. ${ }^{1}$ Obbink took this as proof that Sappho 1 did not come first in the book. ${ }^{2}$ In a forthcoming piece, D'Alessio points out that the lower layer could also contain more of the same roll, but following the top layer, in fact giving the line ends of the verses of Sappho 1 contained on the top layer. ${ }^{3}$

In this article, we present the results of a complete physical re-examination of the papyrus, employing optical microscopy, X-ray tomography, and scanning electron microscopy / energy dispersive X-ray spectroscopy (SEM/EDX) ${ }^{4}$ to obtain topographical, structural, and chemical information at a microscopic scale. The conclusion we have come to is that the lower layer (henceforth B) is most likely not part of the same papyrus as the top layer containing Sappho 1 (henceforth A). The conclusion is based on the cumulative force of six distinct pieces of evidence:

(i) the traces of ink on the recto of $\mathrm{B}$

(ii) the 'missing ink' on the recto of $\mathrm{B}$

(iii) the verso of $\mathrm{A}$ and $\mathrm{B}$

(iv) the fibre structure of $A$ and $B$

(v) mysterious traces on the recto of $\mathrm{B}$ and the verso of $\mathrm{A}$

(vi) the lack of parallels

1 Turner 1973, 25; see below.

2 Obbink 2011, 33-38.

3 D'Alessio forthcoming; a version of the paper was delivered at the Song Regained conference in London, July 2014. We would like to thank him for giving us access to an early version of his article and for sharing his thoughts on ours.

4 The JEOL JSM 6480-LV SEM was operated under low vacuum mode at an accelerating voltage of $15 \mathrm{kV}$; the emitted X-rays characteristic of the chemical elements present at points of interest were captured and analysed with an Oxford Instruments $80 \mathrm{~mm}^{2} \mathrm{X}-\mathrm{MAX}$ detector and INCA software. 


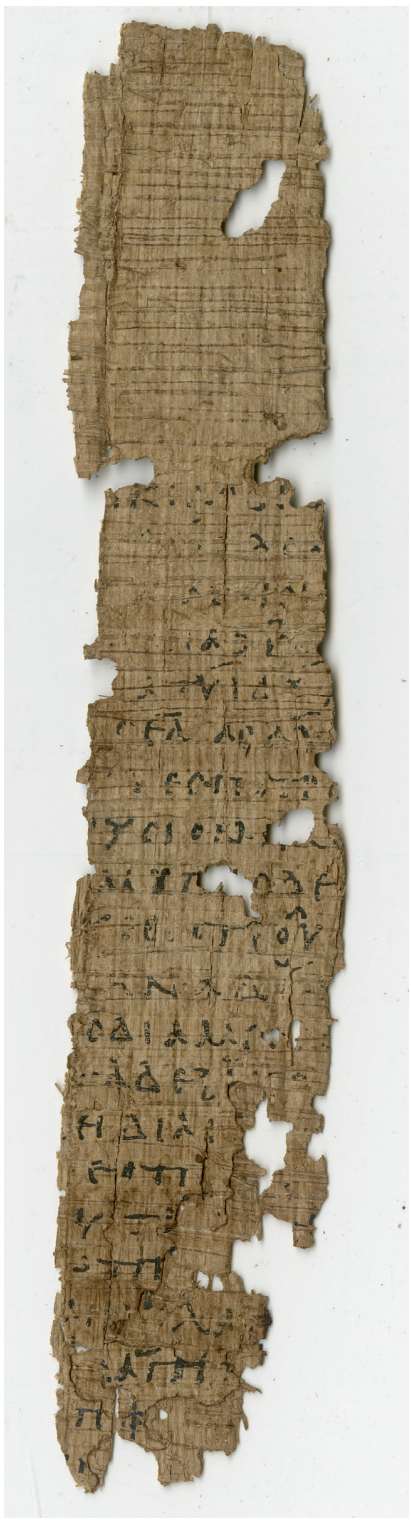

FIGURE 1

P.Oxy. 2288 recto

IMAGE COURTESY OF THE EGYPT EXPLORATION SOCIETY AND THE UNIVERSITY OF OXFORD IMAGING PAPYRI PROJECT.

After setting out the results of our analysis, we re-visit the literary and papyrological evidence for ancient repairs and reinforcements of bookrolls, placing the fragment of Sappho in its bibliological context. 
It is normally assumed by the testimony of Hephaestion that fr. 1 stood first in Sappho's first book, ${ }^{5}$ and the fact that our papyrus starts with line 1 at the top of the column has been regarded as a confirmation of this assumption. ${ }^{6}$ Turner was apparently the first to note the presence of B; he states that "it appears indeed that there are two layers of papyrus in this strip. The lower layer is probably also in the same handwriting. It is that fold of papyrus which lay adjacent to the upper when the book was still rolled up-i.e. part of the same roll of Sappho. At two places the layers can be made to part from each other, and this lower writing can be seen unambiguously". ${ }^{7}$ He says no more about it. Obbink picks up Turner's observation, and builds on its implications. If B contained more of Sappho book 1, and it got attached to it when the book was rolled up normally, it should mean that B contains poems of Sappho preceding the fragment known as Sappho $1 .{ }^{8}$ Building on this assumption, he claims that Sappho fr. 1 can help us reconstruct this hypothetical ode - to the extent that he cites parts of two stanzas. ${ }^{9}$

D'Alessio offers important corrections to Obbink's conclusion. The gist of his argument is that the roll of poetry was rolled up not with the beginning on the outside, but rather with the beginning of the roll at the centre, at what he calls elsewhere the "posizione finale di lettura".10 The pressure at the centre, possibly in combination with a not further-defined 'adhesive agent', caused the inner layers to fuse together. The upshot of this analysis is that the underlying layer would not contain a poem preceding Sappho 1, as Obbink has it, but rather the continuation of the roll, at a distance of around $1.75 \mathrm{~cm}$ after the extant fragment. It would most likely, therefore, contain the line-ends of Sappho 1. D'Alessio mentions one further possibility between brackets, namely that B was added in an ancient repair of the roll, which, as he points out, would have been necessary especially at the extremities of rolls.

To sum up, we may consider the following possibilities for B:

Hephaestion, Encheiridion, p. 43 Consbruch. The metrician adduces the first line of the poem to exemplify the Sapphic hendecasyllable, for which he is expected to use the first line of the first poem in the book dedicated to that metre.

$6 \quad$ Lobel 1951, 1.

$7 \quad$ Turner 1973,25 .

8 Obbink 2011, 36.

$9 \quad$ Obbink 2011, 38.

10 The Artemidorus papyrus can be shown to have been rolled up with the beginning on the inside when it was stored or discarded, cf. D'Alessio 2009 and Bastianini 2009; for further parallels see D'Alessio 2001, 24-25: "Non sono ... rari i casi in cui i danni si sono prodotti quando il volume era arrotolato in posizione finale di lettura”. 
- it is part of the same papyrus roll as A:

- it precedes A and is:

- another poem (Turner, Obbink);

- the agraphon at the start of the roll (between possible protokollon ${ }^{11}$ and first column of writing);

- notes and/or a title written on the first kollema.

- it follows A and is:

- another poem;

- more of Sappho 1 (D’Alessio).

- it is not part of the same papyrus roll as A:

- it is an extra layer added to the papyrus:

- in order to reinforce the end of a much-used roll (D'Alessio in brackets);

- in order to repair a damaged roll;

- in order to strengthen a separate sheet containing only Sappho 1.

- it got stuck to the papyrus accidentally after the roll was discarded.

In the upcoming analysis, we first give a brief description of the papyrus, before going through the different pieces of evidence one-by-one.

\section{$3 \quad$ Analysis}

The make-up of 2288 is such that the vertical fibres of A face the horizontal fibres of B. From the front, we can see the horizontal fibres of A and, where it has become visible, of $B$. The back shows the vertical fibres of $B$ and, where it has become visible, of A. A number of holes go through both A and B, at the edges of which the stratigraphy of the papyrus is clearly visible. However, there are also a number of holes in both A and B that are not shared with the other layer.

\subsection{The Traces on the Recto of $B$}

Looking at the front, the following traces of writing on B can be discerned where A does not cover it, proceeding from the top to the bottom of the fragment. Using a Leica Stereozoom M165 C microscope, we were able to see the traces in detail, and digitally photograph them for the reader's convenience:

- just to the right of lines 13 and 14, there are two traces, apparently from different lines of writing. The top trace is the middle part of an ascending

11 The protokollon preceded the first kollema and had fibres running vertically on the front in order to protect the beginning of the roll. This was not a necessary part of the papyrus roll, and it is not well-attested in the papyrological record; cf. Puglia 1997, 16-19 and Caroli 2007, 52-57. 
diagonal, the ends of which are covered by A. The lower trace is the right end of a horizontal. See fig. 2.

- just to the right of $\tau \tau$ in 1.15 , there is a tear in A which reveals a vertical curving to the left at the top. Just below to the left is a further trace, apparently horizontal, and to the right of that is a short vertical stroke. See fig. 3 .

- just to the right of the $\tau$, below the $\varepsilon$ in $l .16$, a small trace can be seen that appears to be the foot of an upright (the ink does not seem broken at the edge of the line). See fig. 4.

- right underneath the เ of $x] \ddot{\omega} \tau \tau \iota$ in $l .17$ there is a thick line, curving slightly toward the right near the bottom; its top disappears underneath A. At its foot, the trace breaks off because of damage to the papyrus; just to the right are small remains of an ascending diagonal. It is possible (but not necessary) that these are all traces of one single rounded letter. Just to the left of the thick line, there is one further indeterminate trace on a raised fibre. See fig. 5 .

- in 1.18 underneath of the $\nu$ of $\mu \alpha$ ivó $\lambda \alpha$, there is a neat upright, slanting slightly to the right; the top disappears under A; it is unclear whether the foot is extant, or the ink breaks off. See fig. 6 .

- in l. 19, just below the trace of $\sigma$ there appears to be a further trace, though it is not as clear as the others. It looks like a slightly curving vertical, but it may well have obtained this shape because the rest of the ink has come off. See fig. 7 .

Now that we have located the traces of ink on the recto of B, the next step is to describe their physical appearance and the script, as far as it can be discerned. Turner says about B that it is "probably ... in the same handwriting" as A. ${ }^{12}$ In his brief mention of the peculiarity of 2288 , he does not go on to describe the traces, so we cannot know exactly what he had seen to lead him to make his judgment. What we can do is attempt our own comparison of the handwriting of $\mathrm{A}$ and $\mathrm{B}$.

Upon cursory examination, the ink of the two layers does indeed look similar, even if in some places the ink of B looks slightly more faint, e.g. in the horizontal at 1.14 and the upright below 1 . 18. Under extremely high magnification in the scanning electron microscope (SEM), the surface of the ink on B looks decidedly different from that on A. Whereas the ink of the Sappho fragment is thick and caky, and severely cracked, the ink on B looks much thinner (see fig. 9).

As regards the dimensions of the traces, the lack of completely visible letters makes it difficult to judge their size and shape. Nonetheless, we can make 


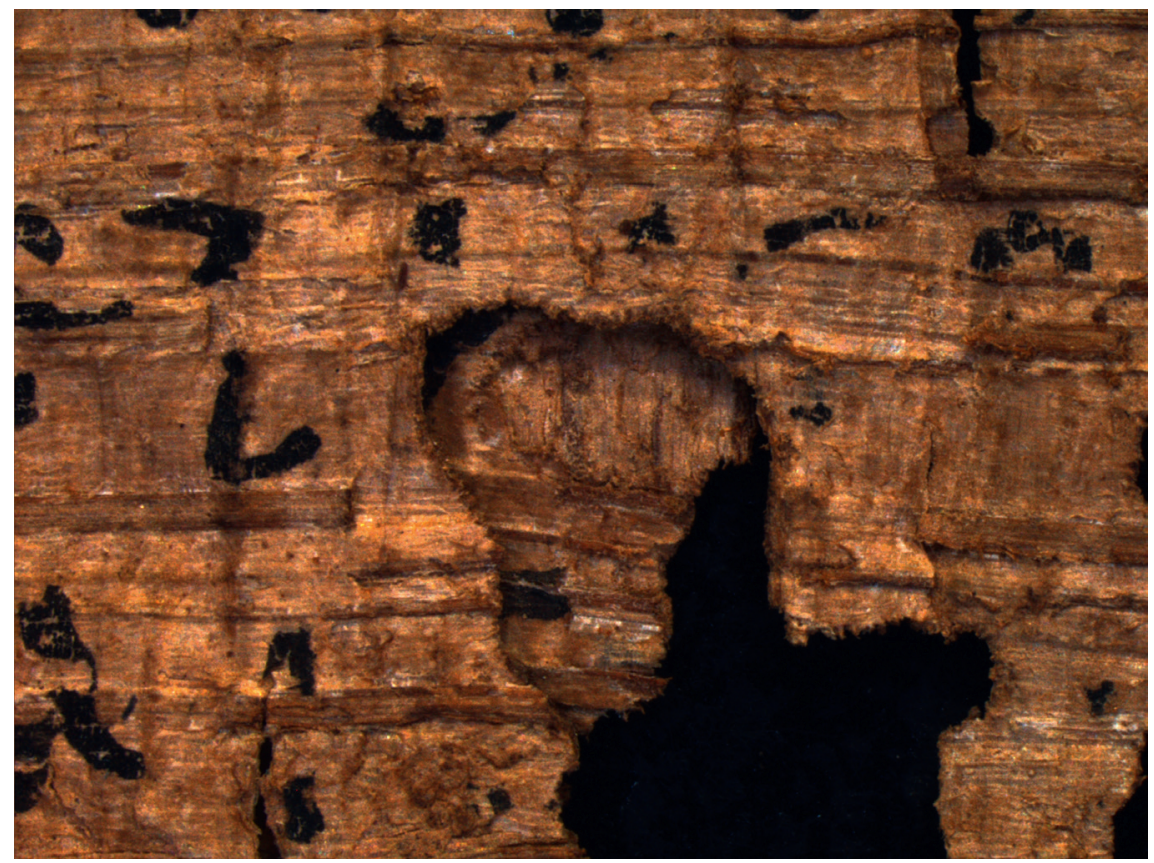

FIGURE 2 traces at ll. 13-14

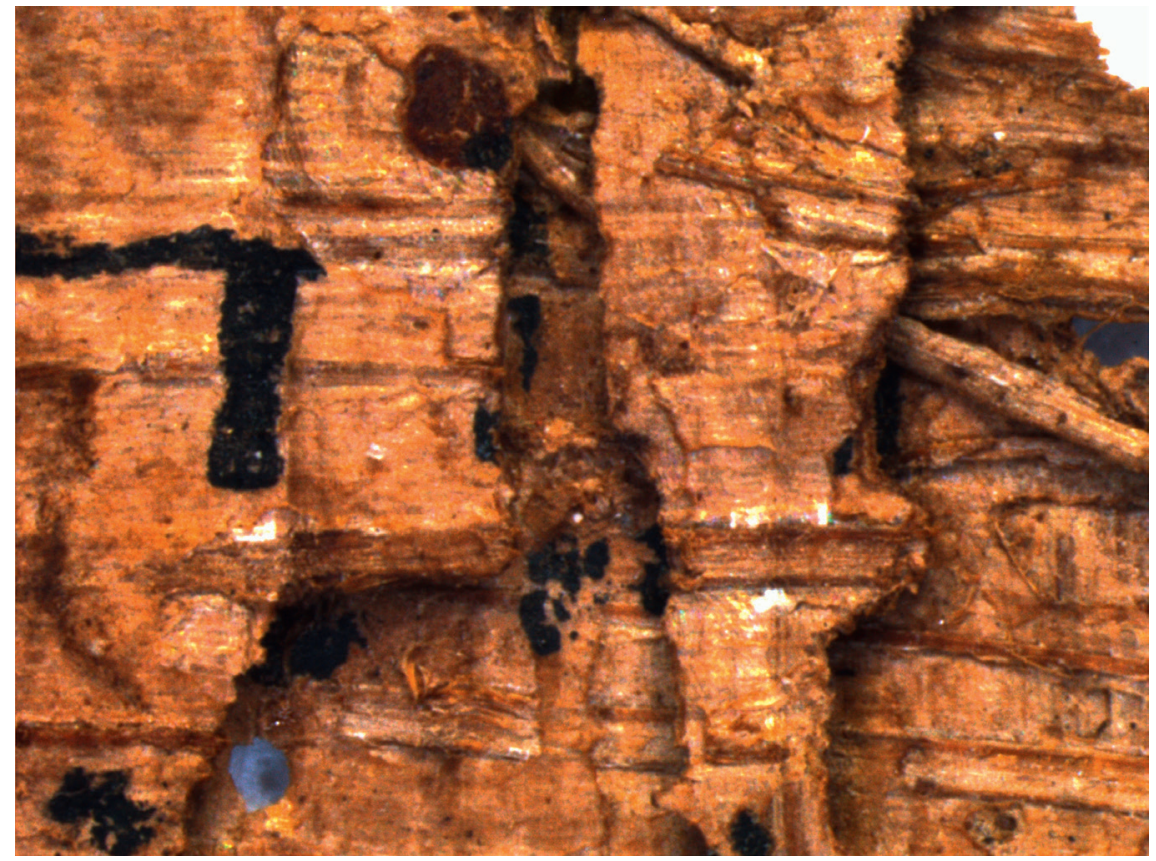

FIGURE 3 traces at l. 15 


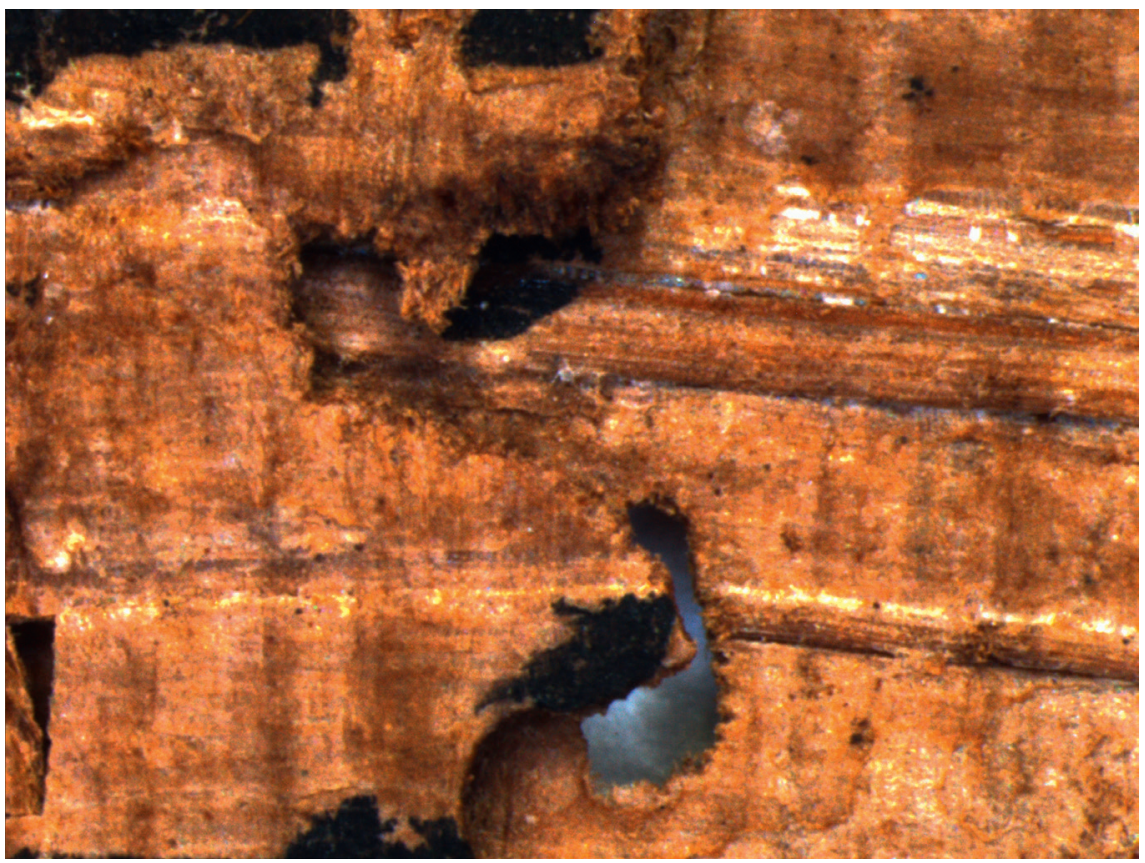

FIGURE 4 traces at l. 16

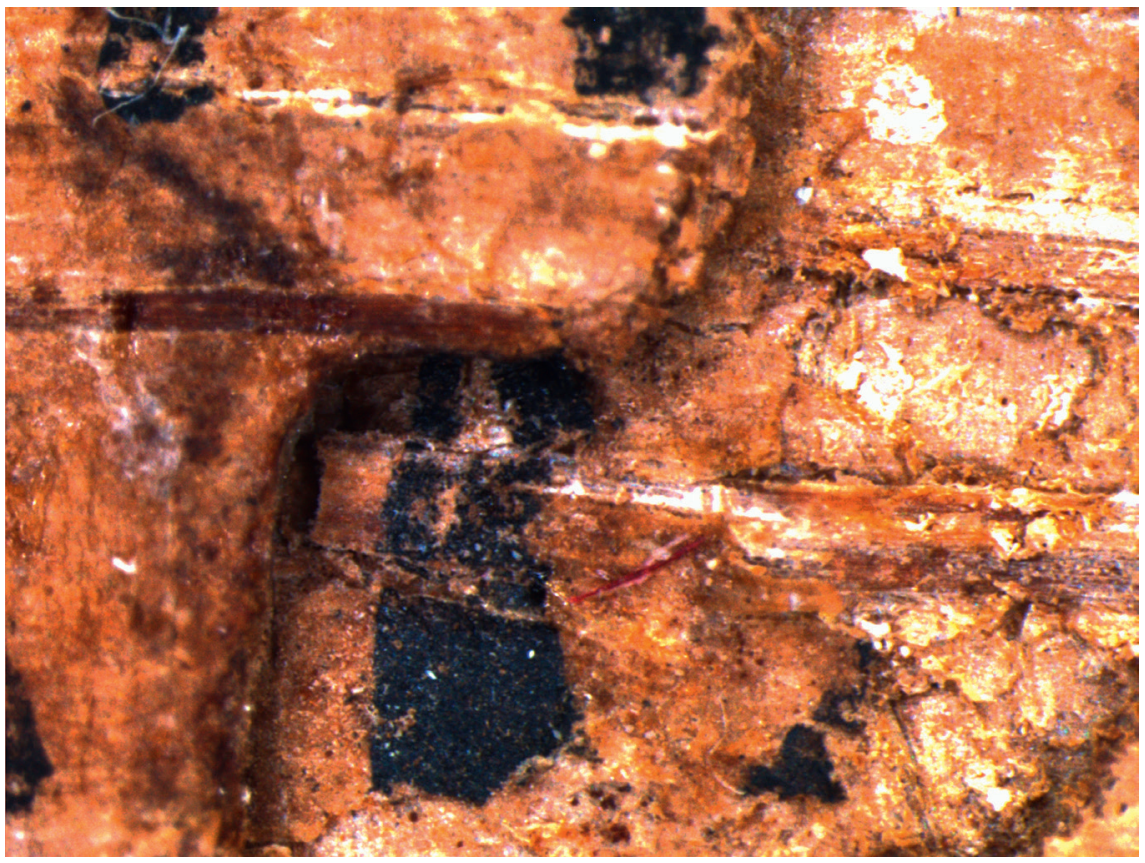

FIGURE 5 traces at l. 17 


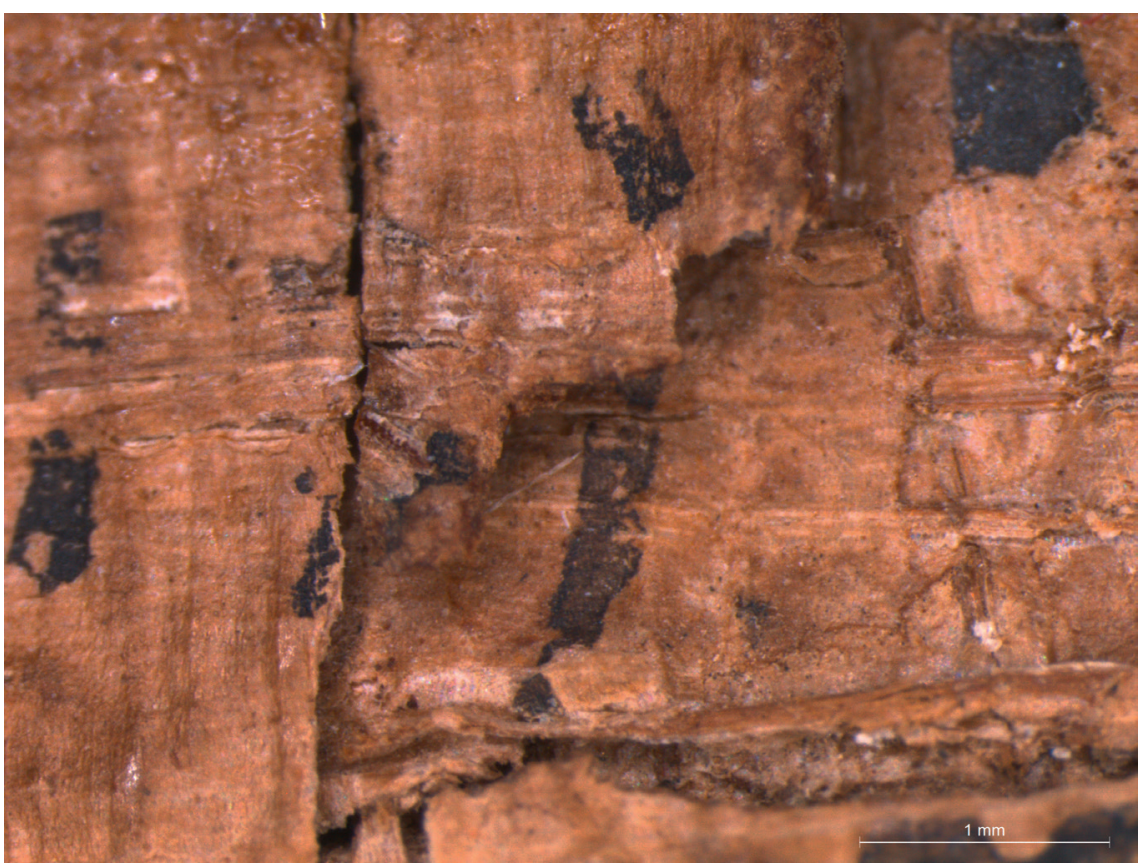

FIGURE 6 traces at l. 18

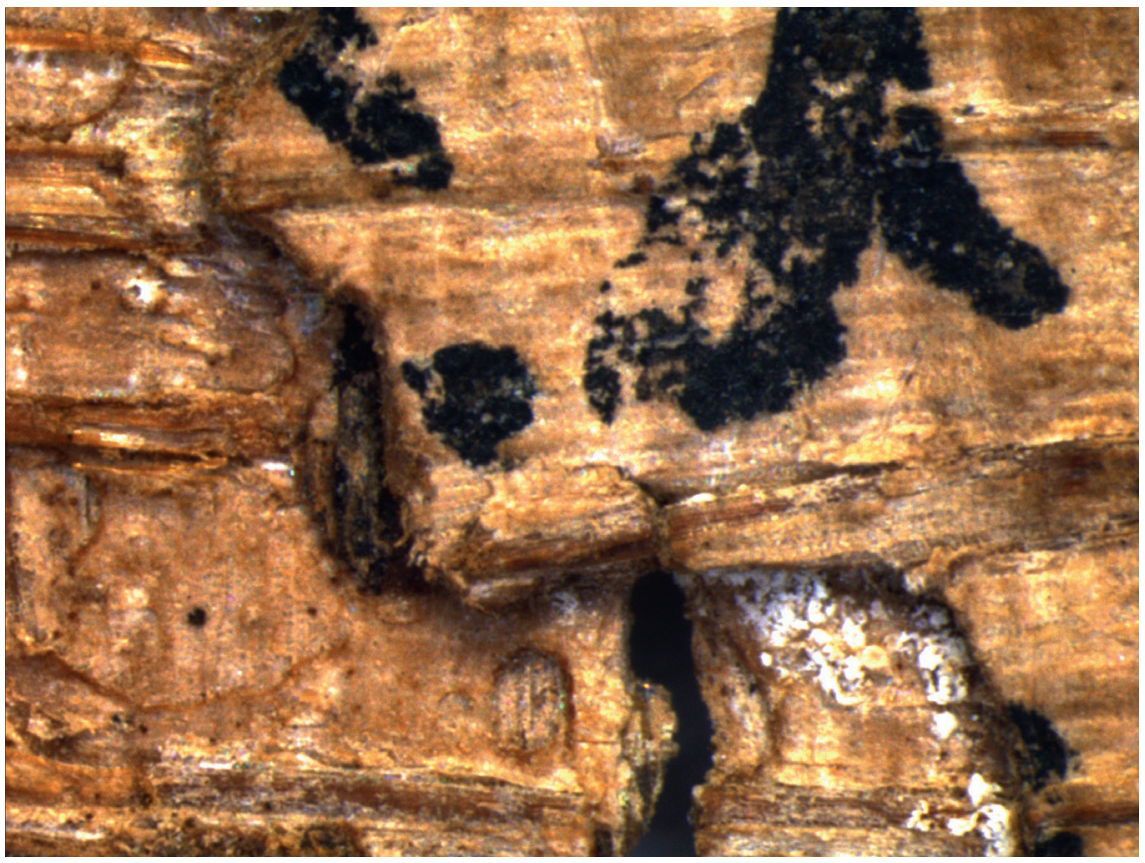

FIGURE 7 traces at l. 19 
a few observations. The trace on B below 1.17 (fig. 5) looks thick in comparison with the extant text on A, the only good parallels being the $v$ of 1.9 and the left upright of the $\eta$ of l. 19. If the traces taken together are remains of a rounded letter, e.g. $\sigma$ or $\omega$, it looks decidedly larger than its counterparts on A. The scribe of the Sapphic verses wrote the $\sigma$ narrow, and the $\omega$ of 1.17 is clearly less tall. The horizontal trace on B to the right of 1.14 (fig. 2) is less thick, but it does not match the consistently thin crossbars of $\pi$ and $\tau$ in A. Finally, consider again the traces that emerge from the tear in 1.15 (fig. 3). Since the traces are written so closely together, and the bottom right trace looks like a foot, it is most likely that the entire set belonged to the same line of writing.

Now, the upright of the $\tau$ in 1.15 is around $2.8 \mathrm{~mm}$ tall, whereas the set of traces visible on $B$ is around $6.4 \mathrm{~mm}$ tall. The only single letter of that height on A is the $\varphi$ of 1.20 , but none of the traces on B are easy to reconcile with this letter. Alternatively, it could be a letter or group of letters with diacritics written over it, but the top part of the visible traces is clearly an upright.

To sum up, although none of the visual traces on the recto of B positively exclude the possibility that it contains the same script as A, some of the visible ink does not straightforwardly match any of the letter shapes on A. Turner's conclusion, and Obbink's tacit endorsement, cannot stand without reservation.

\subsection{The Missing Ink on the Recto of $B$}

Since we know that there was writing on the recto of B, it is surprising that all the remaining traces are to be found at the very edge of those places where $\mathrm{B}$ has become visible. Especially to the right of 1l. 13-17, large patches of B are visible, with no ink on it whatsoever. D'Alessio explains this by regarding the traces as line ends, and the empty spaces as the intercolumnium. ${ }^{13} \mathrm{~A}$ close examination of the papyrus may provide a different explanation.

If we look again at the images, and we focus not on the ink traces, but on the surface of the papyrus, we discover a further physical peculiarity of 2288 . Although in many places we can see the horizontal fibres of B, so that we may believe we are looking at the surface of B, they have in fact been stripped of their uppermost stratum. This is particularly visible in figures 2 (horizontal in l. 14) and 5 (upright in 1. 17), where the traces of ink break off exactly where this surface layer has come off. We can see the same pattern in fig. 3, where the trace in the bottom right is limited only to the strip of the top layer of B that 
remains. To the left and right of the strip, the underlying fibre structure is visible, and the surface is altogether lighter in appearance.

With this knowledge, we may look more closely at those places where patches of B are exposed. Consider first fig. 8 (ll. 15-17). In this part of the papyrus, we can trace the edge of the darker-looking top surface of B, especially clear in the side-view image in fig. 10. At the bottom of fig. 8, to the right of the trace of ink, we can see that the surface of B is largely abraded; in a patch in the bottom right even the horizontal fibres are not completely extant. Further down, as seen in fig. 7 (l. 19), the top surface of B is almost entirely gone except directly underneath the edge of $\mathrm{A}$.

In two places, parts of the surface of $B$ are still attached and visible (see fig. 8): to the right of the interlinear space between ll. 16 and 17 of A, the top surface extends to the right between two horizontal fibres. The same is true to a slightly lesser extent to the right of the foot of the $\iota$ at the papyrus edge in l. 17 . Between these two horizontal 'strips', the edge of the surface of B roughly runs parallel to the edge of A.

Those places where the ink breaks off exactly as the surface is no longer visible show that the ink had not penetrated deeper than the top stratum. We are therefore justified in believing that in those places where the surface is no longer extant, any writing that may have been there has also been lost. By extension, the lack of ink traces on those parts of $B$ need not indicate the absence of writing, but only the absence of the B's surface stratum. The fact that the top stratum of $B$ is stripped to such an extent where $A$ is no longer there, may be explained if $\mathrm{B}$ had become attached to $\mathrm{A}$.

\section{$3 \cdot 3$}

\section{The Verso of $A$ and $B$}

Probably because the back of $B$ is completely devoid of ink, previous discussions of 2288 make no mention of the verso. As mentioned above, however, there are a few places in which we can see the back of A, and in one place there appears to be a trace of ink.

- At the edge of one hole, roughly at the height of 1l. 11-12, there is a trace of ink at the very top; it looks like a slightly descending horizontal, but the ink breaks off at the edge. See figs. 11 and 12.

As is the case on the front of the papyrus, in places where B has come off, it has taken with it the top stratum of the underlying papyrus, in this case A. As a result, most ink that could have been on the verso of A is no longer visible. The fact that the verso of the Sappho papyrus had writing on it while B ostensibly did not is a further argument to consider that B is not more of the same roll. 


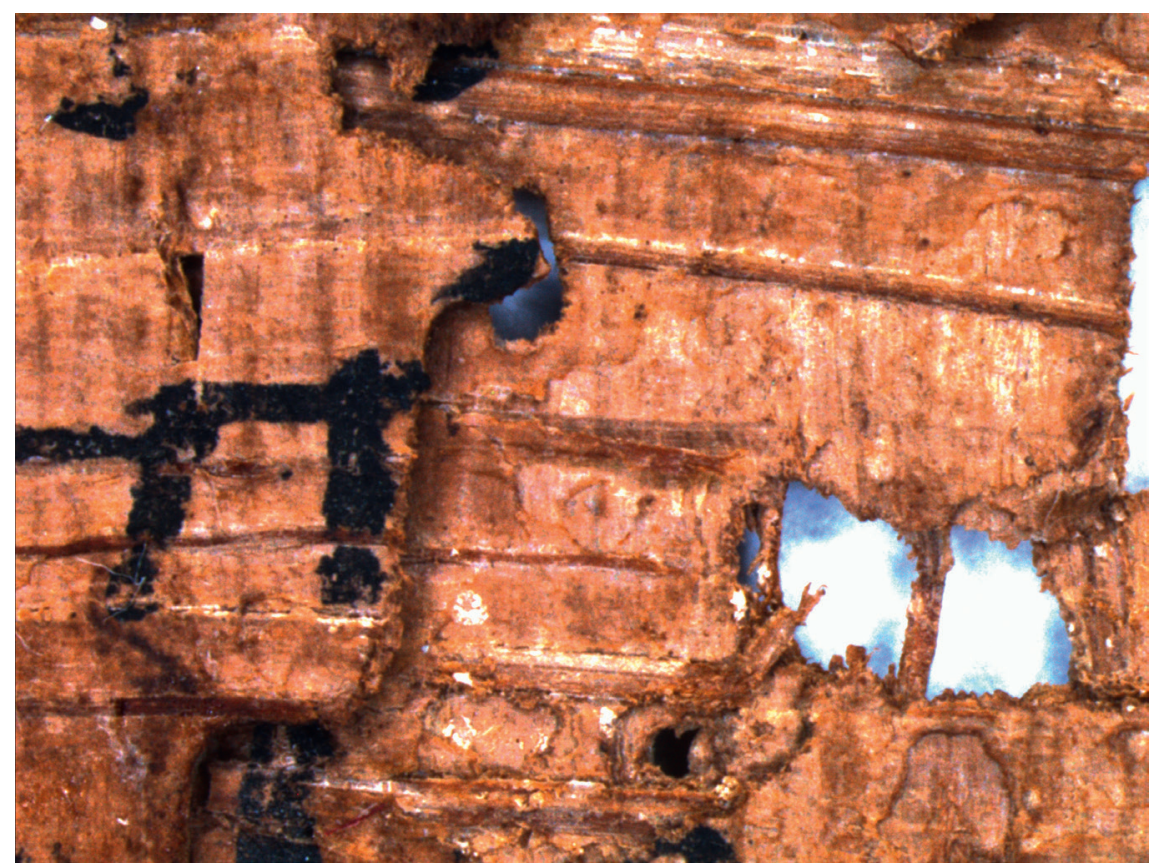

FIGURE 8 surface stripped at ll. 15-17
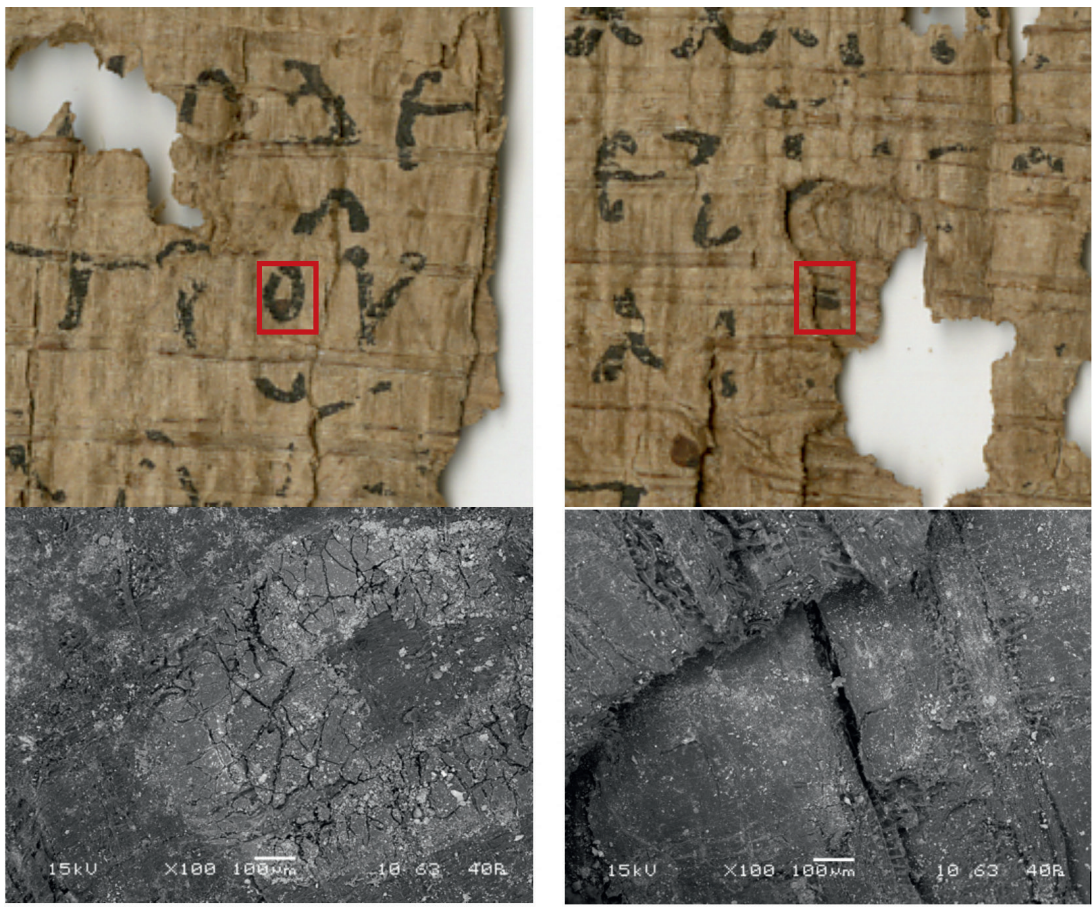

FIGURE 9 comparison of ink on A and B under SEM (magnification $\times 100$ ) 


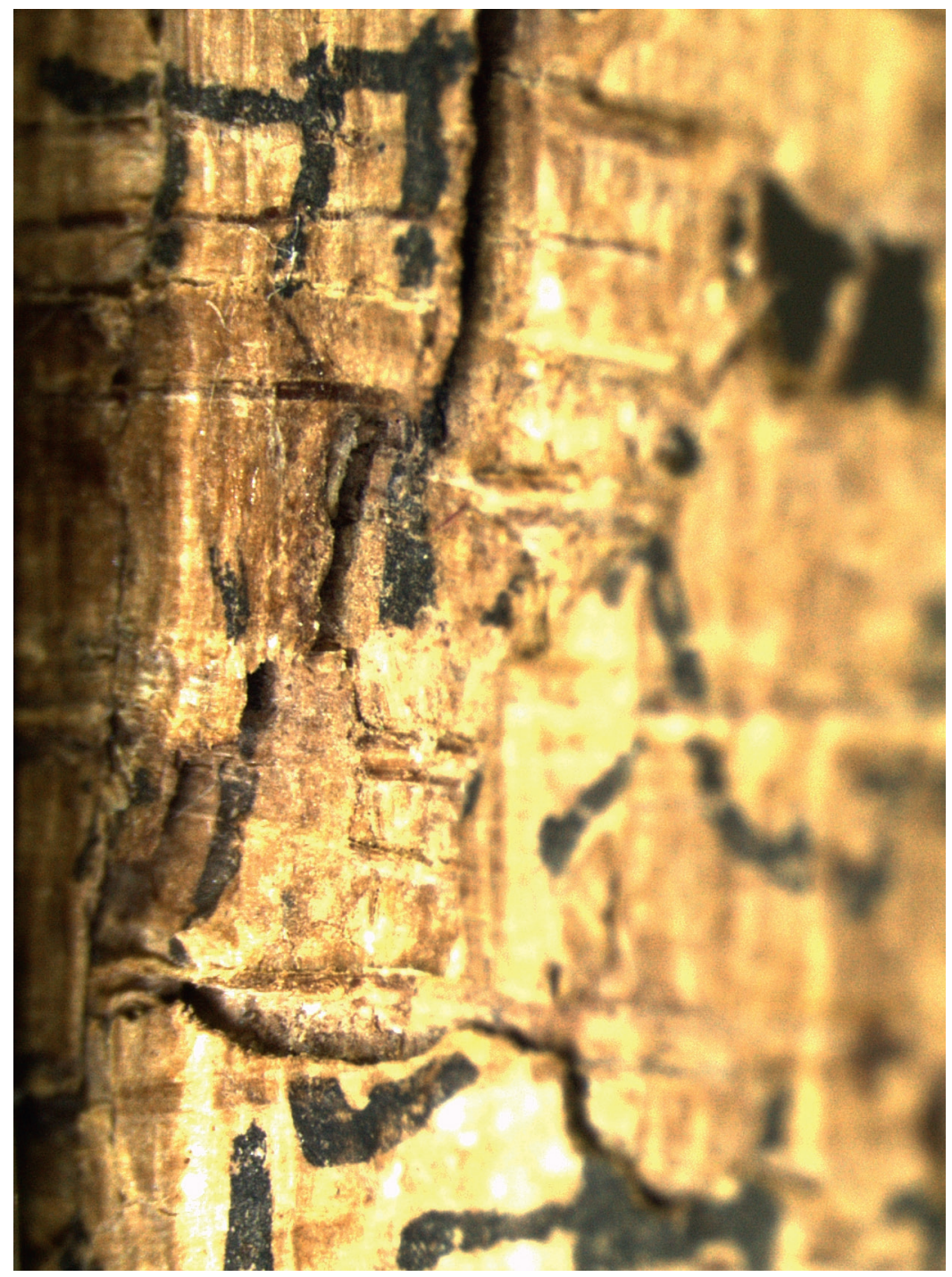

FIGURE 10 side view of ll. 16-18

\subsection{The Fibres of $A$ and $B$}

If $B$ is indeed more of the same roll, then we should be able to see a continuation of fibres, placing B either to the left (Obbink) or to the right (D'Alessio) of A. If Obbink is right, and Sappho 1 did not stand at the beginning of Book 1 of Sappho, then we cannot establish the place of these two layers in the roll, nor establish the amount of papyrus lost between them. If D'Alessio is right, and the text was rolled up "in posizione finale di lettura", our piece would come from very close to the middle of the roll. D'Alessio adduces comparative 


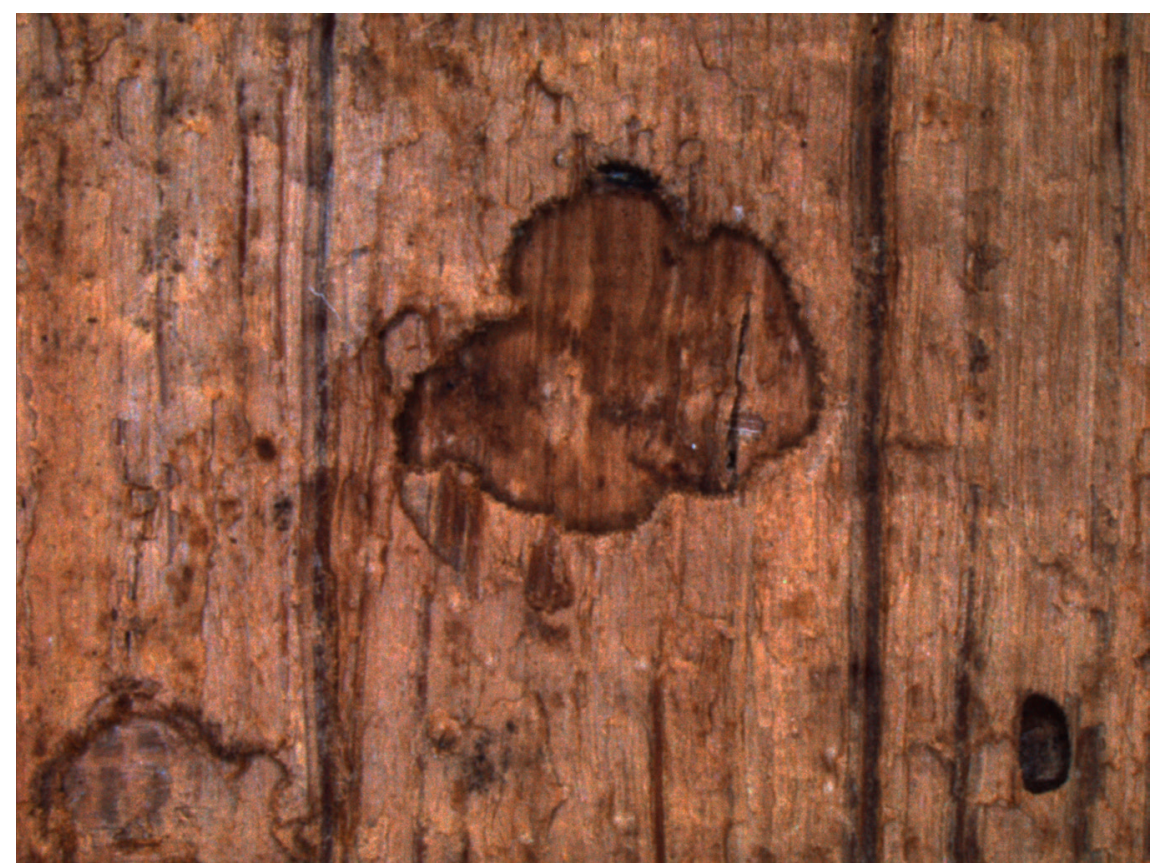

FIGURE 11 hole in verso of B

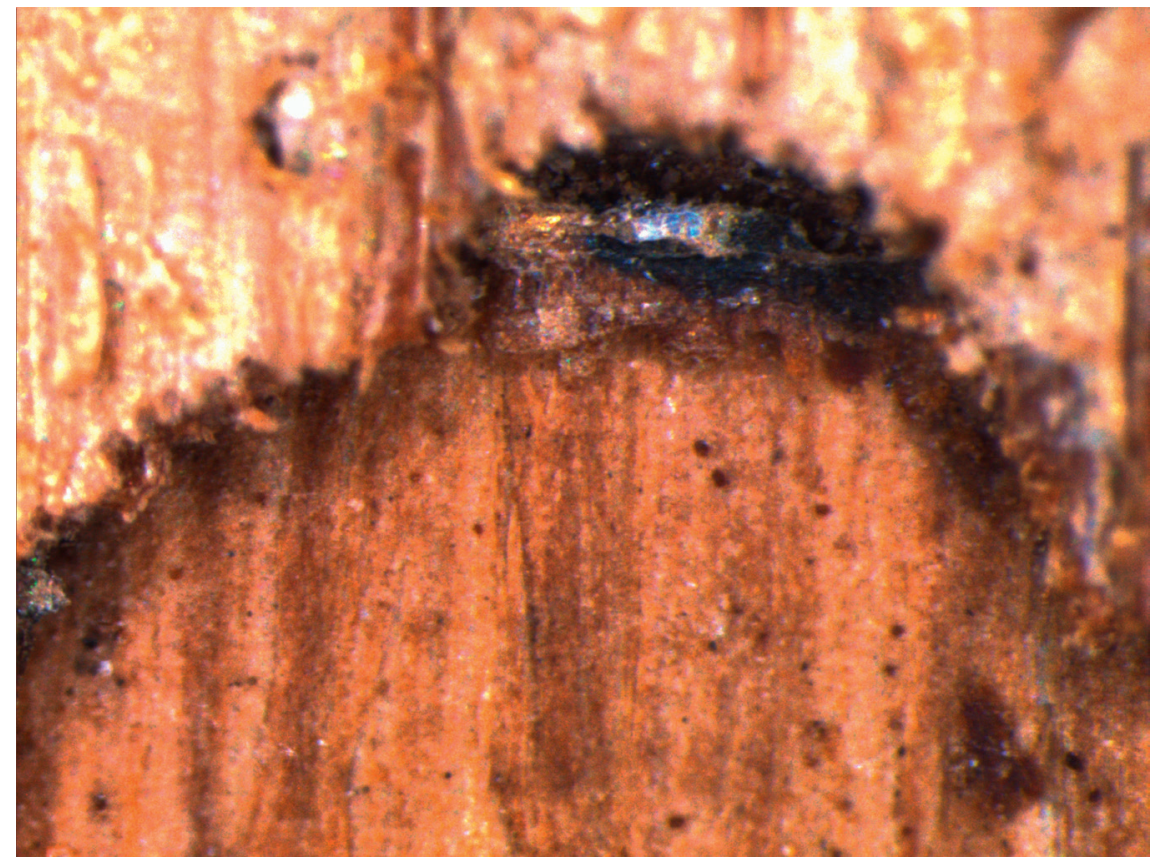

FIGURE 12 hole in verso of B, detail: trace on verso of A 
evidence from Herculaneum rolls to argue that the amount of papyrus lost between the two layers would be around $1.75 \mathrm{~cm} .{ }^{14} \mathrm{He}$ concludes that B must have contained the line ends of Sappho 1.

Especially if we follow D'Alessio, and both layers formed part of the first column of writing in the roll, we are justified to believe that A and B should form part of the same kollema. Moreover, the short distance between them should mean that we can see a clear continuation of the fibre pattern. If Obbink is right, then the distance between B and A may have been substantial, leaving ample space for a kollesis to have occurred between them, obviating any continuation of horizontal fibres.

In order to study the fibre structure of $\mathrm{B}$, which is only visible in a few places, 2288 was scanned with X-ray tomography at Begbroke Science Park. Computed tomographs of the fragment were generated using an ImagiX CT system (North Star Imaging Inc., Minnesota, USA).${ }^{15}$ The isotropic voxel size was 29.6 / $20.1 / 16.3 \mu \mathrm{m} .{ }^{16}$ The tomographs were subsequently visualised using an efX-ct software.

Because of the shape of the papyrus (long and thin) and the nature of the setup (a very slowly rotating mount), the scan is not without issues, and the fibre structure of A and B can only be shown in a composite picture, taking parts of different layer images. Fortunately, horizontal fibres of A are largely straight, whereas those of B descend slightly but consistently, as can be seen in e.g. figs. 4 and 8. This aided in identifying to which layer the fibres belonged. The difficulty of strictly separating the fibres may be illustrated (see the arrows in fig. 13) by the complex of fibres belonging to B (note how it descends), but showing up in the slice of A as well.

Lining up the two images next to each other, we have not been able to establish a good fibre match between the fragments. We may look for example at the three bright fibres in A separated by dark bands near the bottom of the image, the top fibre slightly further removed from the middle fibre than the bottom one. No such pattern emerges from B. In the middle part of the fragment, the difference between the two layers is more evident: whereas A appears to generally have widely spaced horizontal fibres, the pattern of B shows thin fibres at brief intervals, almost without exception.

14 D'Alessio forthcoming.

15 Equipment funding for the ImagiX CT system was provided by EPSRC Grant EP/Jo13501/1.

16 The cone beam projections were captured under the following conditions: 40 / 50 / 80 kV tube voltage, 500 / $420 / 110 \mu \mathrm{A}$ tube current, and a frame rate of $1 / 1.5 / 1 \mathrm{~Hz}$. 


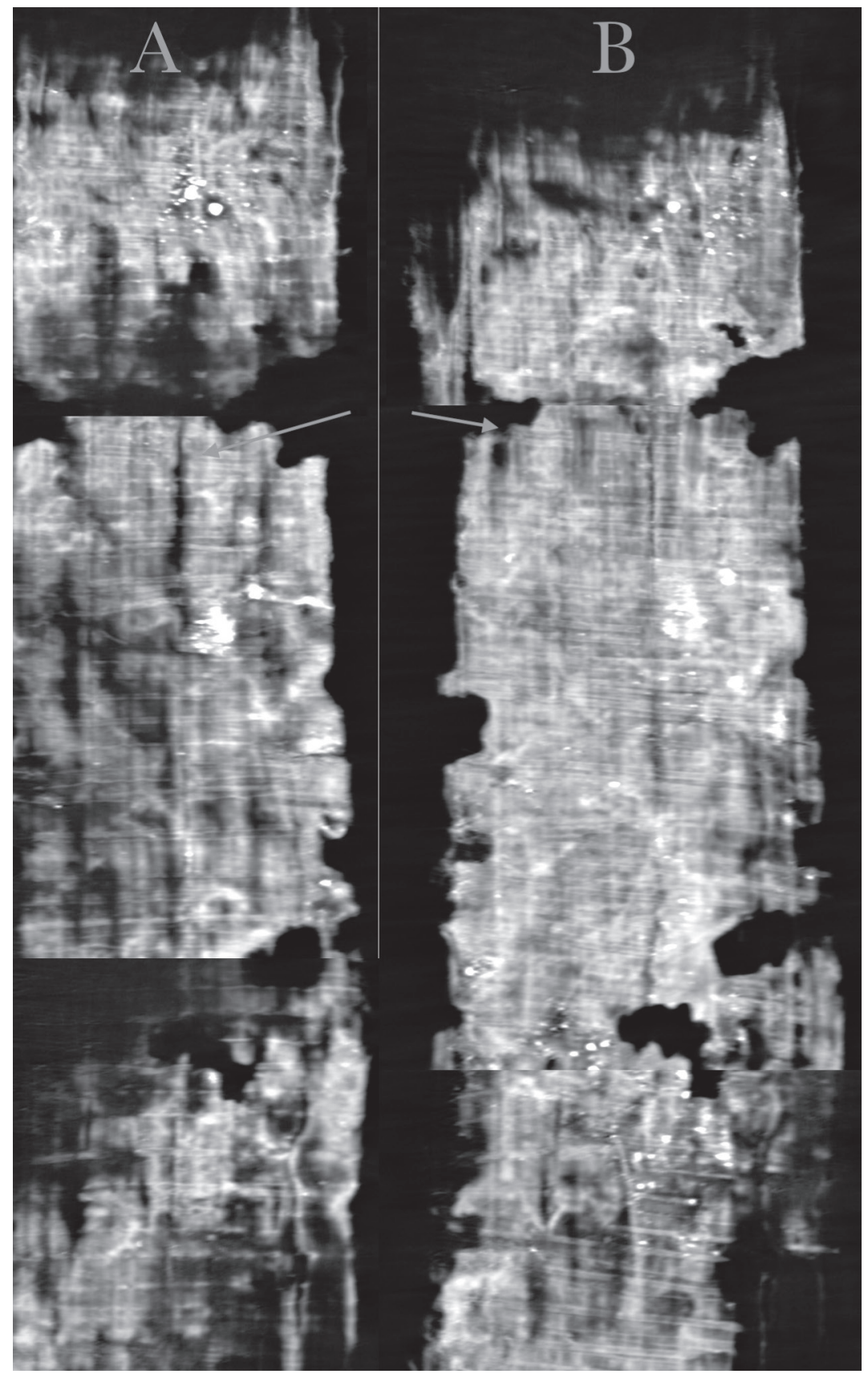

FIGURE 13 X-ray tomographs of A and B 
The problems of both imaging and of interpreting the images are sufficient reason to treat this analysis with the necessary reservations. Rather than proving that the fibre structures of A and B do not match, we would regard it as not proving that $\mathrm{A}$ and $\mathrm{B}$ share the same pattern of horizontal fibres.

\subsection{The Mysterious Traces at ll. 19-20}

Around the edge of A, to the left of the interlinear space above $\varphi(1.20)$, there is a remarkable white residue (fig. 7 and fig. 14). Chemical analysis with scanning electron microscopy / energy dispersive X-ray spectroscopy (SEM/EDX, see n. 4 for operating details) detected high levels of calcium, sulphur and oxygen in the residue, strongly suggesting the presence of calcium sulphate. One possible candidate is gypsum, a key ingredient in gesso or plaster. In this form, gypsum is a common ingredient in the preparation of cartonnage, where papyri and textiles were glued together to create mummy covers. ${ }^{17}$ This could lead us to believe that 2288 was part of cartonnage, especially considering the fact that it consists of multiple layers of papyrus. ${ }^{18}$ Nonetheless, the fragment shows no further sign of having been taken from cartonnage, a process that tends to leave clear traces of plaster on the surface of the papyrus. Further white traces on the surface of A, also visible on fig. 14, did not share the same chemical composition.

An alternative possibility is that the traces are remains of the adhesive used to attach B to A. Newman and Serpico also mention that "... some residues of ancient Egyptian adhesives in museum collections have a noticeably pink colour. These are generally powdery in consistency and may be the remains of a gesso, perhaps intentionally tinted ...."19 They are hesitant about their conclusions, but they allow that gesso was used as adhesive; elsewhere they mention gypsum specifically as an adhesive. ${ }^{20}$ Plin. Nat. 13.82 mentions two kinds of wheat starch paste used as glue in the papyrus production process; no other glues are known from ancient sources. ${ }^{21}$ When studying the make-up of

\footnotetext{
17 See Scott et al. 2003 for a recent discussion.

18 The date of the hand (2nd century CE) is a further reason to doubt the possibility that the fragment came from cartonnage: by far most papyri from cartonnage date to the Ptolemaic period; cf. Cuvigny 2009, 45 .

19 Newman and Serpico 2000, 481.

20 Cf. Newman and Serpico 2000, 475: "Inorganic adhesives ... such as clay, gypsum ...".

21 Wheat paste is also mentioned in Dsc. Mat. Med. II 85, p. 170 Wellmann: xó $\lambda \alpha \alpha \delta \dot{z} \dot{\eta} \gamma\left(v 0 \mu \varepsilon^{\prime} \eta \eta\right.$

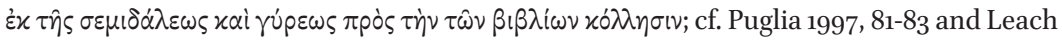
and Tait 2000, 236-237 for a discussion of the process.
} 


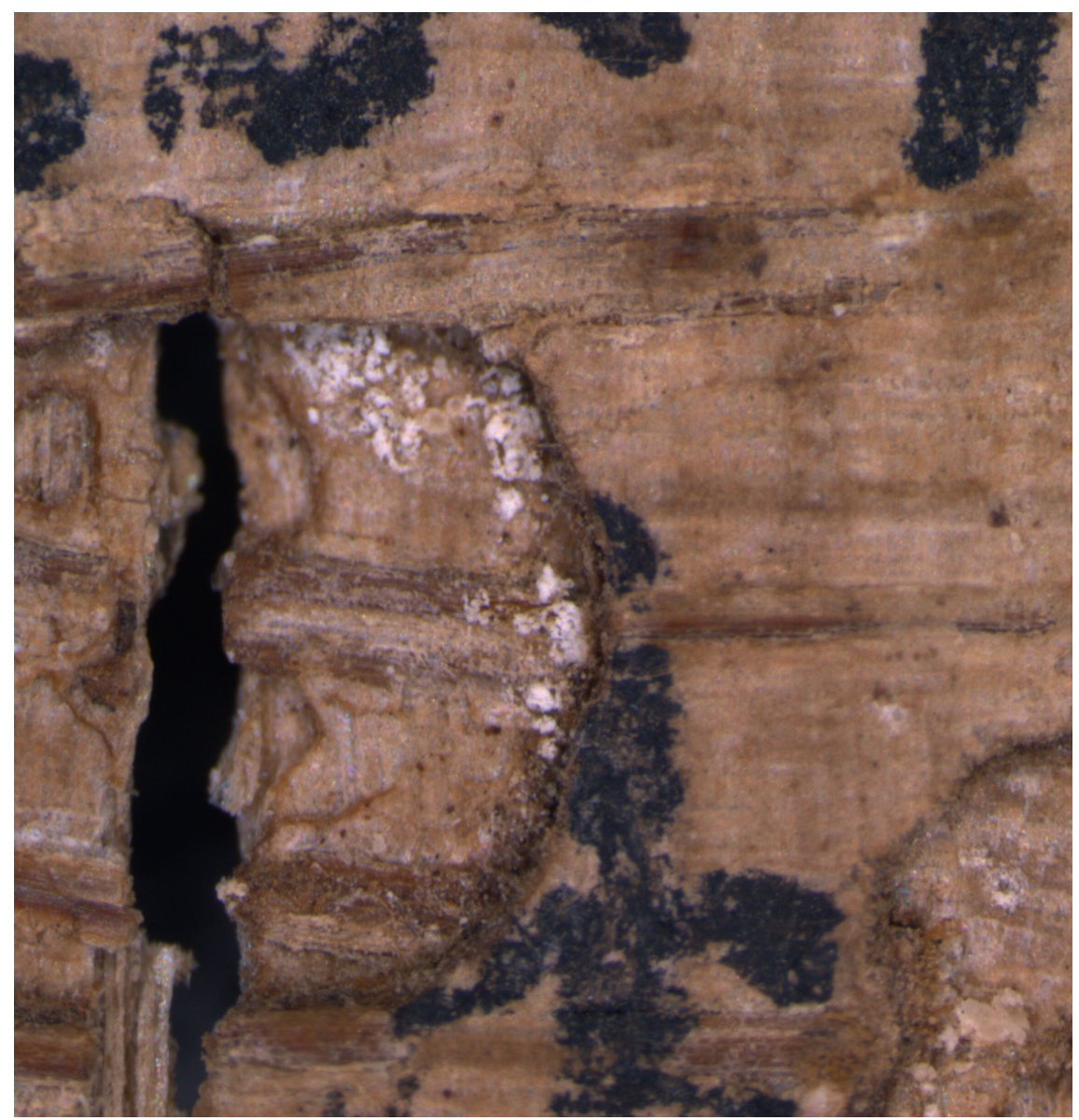

FIGURE 14 white traces over l. 20

a number of papyri from the Louvre collection, this wheat starch is the kind of glue that Flieder et al. found. ${ }^{22}$

P.Mil.Vogl. 205 (discussed more extensively below) may provide a relevant parallel. The rectangular sheet of papyrus was apparently glued onto a single damaged column of a roll of Thucydides' Histories, but in the course of history became detached again. The editor reports "uno strato di patina biancastra", a white patina on the side that would have been glued onto the roll of Thucydides, which could have been the remains of adhesive. ${ }^{23}$ Cavallo and Puglia are more

22 Flieder et al. 2001, esp. 92-95.

23 Bartoletti 1960, 61 for the first quotation, and 66 for the comment about adhesive: "in origine poté essere costituita da materia collosa". 


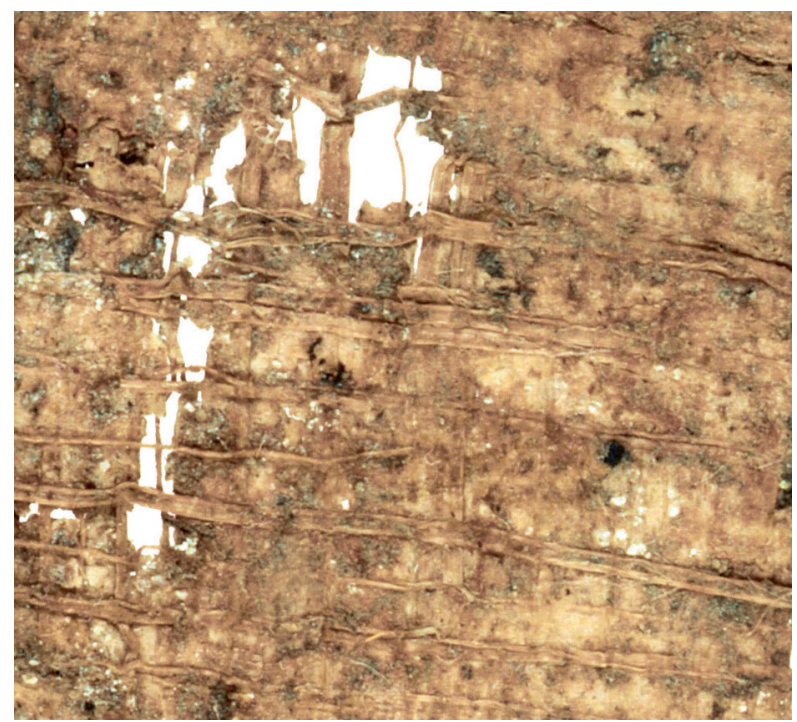

FIGURE 15 P.Mil.Vogl. 205 recto, detail

confident that these white stains are traces of glue. ${ }^{24}$ Although we have not had the opportunity to test the chemical composition of these traces, an excellent image of the papyrus confirms that the traces look very much like those around the edge of A described above (see fig. 15). ${ }^{25}$ Nevertheless, only further physical and chemical analyses of other repaired papyri will allow us to establish whether gypsum or gesso was in fact used as an adhesive.

\subsection{The Lack of Parallels}

In his discussion of 2288, Obbink says the following about B: "[t]his phenomenon is familiar from the rolls of the Herculaneum papyri, which were carbonized by the eruption of Vesuvius in AD 79, then broken into pieces containing more than one layer of papyrus by archaeologists in the eighteenth century. But it is occasionally exampled also by papyri of Egyptian provenance." Unfortunately, he gives no references for these possible parallels from Egypt.

Since many papyri were stuck to other fragments or to themselves at the moment of discovery, but subsequently detached by the papyrologists that had to conserve them, it is difficult to know where to search for further parallels.

24 Cavallo 1986, 133 speaks of "quasi sicuramente, tracce di colla", while Puglia 1997, 37 claims: "senza dubbio, colla".

25 We would like to thank the 'Achille Vogliano' Papyrology Centre for providing the digital images of P.Mil.Vogl. 205, and Prof. Gallazzi for his kind assistance. 
Most fragments surfaced from the sands in crumpled clumps, and they were first flattened and separated by wetting and spreading them out. ${ }^{26}$ Clearly, the layers of 2288 did not detach even in this process. Since no further fragments were published with it, we have to assume that no further pieces with the same handwriting were found near it, let alone attached to it.

D'Alessio suggests that the pressure on the inside of the roll, in combination with an undefined "adhesive agent" (see section 3.5 above), caused the layers to stick together. ${ }^{27} \mathrm{He}$ adduces the parallel of P.Stras. 901, remains of a documentary roll in which extensive 'fibre migration' has taken place. This means that as the papyrus was rolled up, vertical fibres of one layer stuck to the horizontal fibres of the next layer over, or even that entire layers stuck to another. ${ }^{28}$ The adhesive would have been provided by the material itself or the context of its conservation: "papyrus lui-même, humidité, salinité, salpêtre, boue, etc.." ${ }^{29}$ The Strasbourg papyrus is an interesting case, but differs from 2288 in showing clear detachment of fibres or fibre layers. As the fibre migration would take place as the layers of the roll were pressed together over time, it can be expected that multiple fragments of the roll would be found in one place. This was indeed the case for P. Stras. 901, but there is no evidence that 2288 was found in the presence of further fragments in the same hand. To our knowledge the best parallels of fragments with multiple layers found in Egypt are those cases where papyrus rolls were repaired or reinforced in antiquity.

The conclusion that presents itself after considering this holistic analysis of 2288 is that B was intentionally attached to the back of A in antiquity. In the present section, we explore the possible reasons for this added layer of papyrus, reviewing the literary and documentary sources before moving on to papyrological parallels.

\subsection{Literary and Documentary Evidence}

The practice of repairing or strengthening the extremities of the papyrus roll is well attested, since they were the parts most likely to be weakened or

\footnotetext{
26 Cf. Leach and Tait 20oo, esp. 243-248.

27 D'Alessio forthcoming.

28 Chang 2014, 31-32.

29 Chang 2014, 31.
} 
damaged. ${ }^{30}$ We may start from the engineer Hero, who explains at the start of book 2 of his Mechanics why he discusses different cranes at length: xai үàp

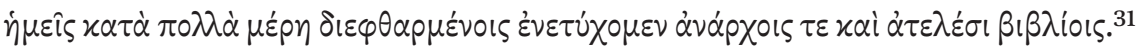
In his own search for information, Hero had apparently come across a number of books that were $\ddot{\alpha} v \alpha p x \circ \varsigma$ and $\dot{\alpha} \tau \varepsilon \lambda \eta \dot{\eta} \varsigma$, without beginning and end, and damaged in many places. Hero's story is particularly informative for our case, since he probably worked in the Alexandrian Mouseion in the first century CE. ${ }^{32}$

Lucian, in his diatribe against the ignorant book collector, discusses what can be done about this deterioration, mentioning the 'gluing ( $\delta 1 \alpha x 0 \lambda \lambda \alpha \omega)$ and trimming' of bookrolls. ${ }^{33}$ Although the meaning of $\delta 1 \alpha \kappa o \lambda \lambda \alpha \omega$ here is not immediately clear, Puglia interprets it as referring to minor repairs such as "rinforzare i rotoli nei punti che presentavano sdruciture applicando sul loro dorso delle toppe di papiro". ${ }^{34}$ See below for further discussion of the term.

Two documentary texts from the early second century, belonging to a family archive found in Tebtunis, P.Fam.Tebt. 15 and 24, offer further insight into the conservation and restoration of damaged rolls. The first, dated to $114 \mathrm{CE}$, is a copy of a report with annexed documents (dating back to $98 \mathrm{CE}$ ) and the second, dated ten years later, reports a trial with annexed documents. They concern a long legal dispute about the bad state of conservation of the documents in the public archives of the Arsinoites, a situation allegedly due to the negligence of the officials and the clerk in charge..$^{35}$ In the initial report, Isidorus, who has been tasked with estimating the cost of restoring the documents, deplores the current state of the archive:

3o See Puglia 1997, 16-17 and passim.

31 Hero, Mechanics 2.1, quoted in Pappus, Synagoge, book 8, p. 1116 Hultsch.

32 The dates of his life are not known for certain, except that he refers to Archimedes and is himself quoted by Pappus. His first-century date is extrapolated from the likelihood that he refers to the lunar eclipse of $62 \mathrm{CE}$. Cf. Folkerts 2005, 244.

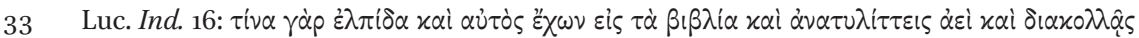

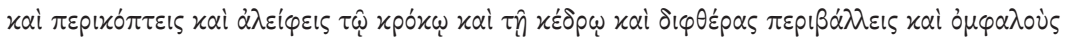
हेviंins;

34 Puglia 1997, 86-87.

35 For a summary of the dispute, which lasted more than forty years even involving the heirs of the original parties, see P.Fam.Tebt. 24, pp. 97-108; cf. Kruse 2002, 784-786, 805-806. For the end of this legal case and updated bibliography see also P.Coles 20 (133 CE or later). Further reference to the bad state of affairs in the archives is made in the decree by the Roman prefect Mettius Rufus cited in the Dionysia petition (P.Oxy. 237, col. viii ll. 27-43); on Mettius Rufus' decree, see Burkhalter 1990, 199-200. 


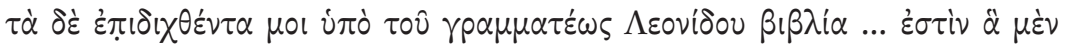

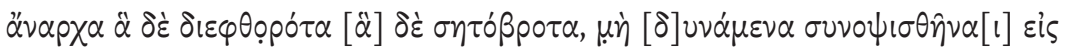
$\delta ![\alpha \alpha \dot{\prime} \lambda \lambda \eta \sigma] ! \varphi^{36}$

The documents shown to me by the clerk Leonidas ... were in some cases deprived of their beginning, or damaged, or moth-eaten, and do not allow an estimation of the cost of the $\delta \iota \alpha x^{\prime} \lambda \lambda \eta \sigma \varsigma$.

Since these are documents, $\ddot{\alpha} v \alpha p x o \varsigma$ need not mean the same as it does in the Hero passage discussed above. Documents may have taken the shape of sheets as well as rolls, so 'missing their beginnings' may here in fact mean 'missing their tops' ${ }^{37}$ Further down, we are informed as to why the documents arrived at such a state:

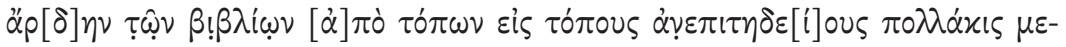

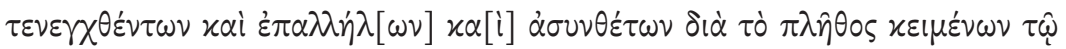

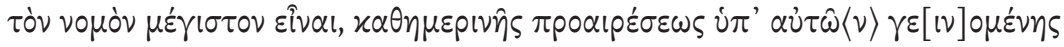

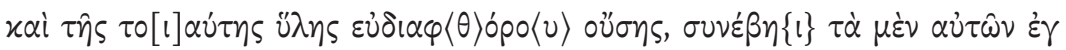

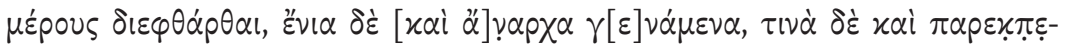
$\pi[\tau \omega] \chi \varepsilon \dot{v} v \alpha ._{.}^{38}$

Since the books have been hastily moved from one place to another, repeatedly, lying on top of each other and unattached, due to the quantity, since the nome is so large, and since they are being handled daily, and their material is brittle, it happened that some were destroyed in parts, some others were without beginnings, and some had even fallen apart.

36 P.Fam.Tebt. 15, ll. 35-37 (transl. by the authors); cf. also ll. 46-47, 52-53, 71, 77-80, 82-83, 88, 95-96; P.Fam.Tebt. 24, ll. 65-66.

37 The same thing appears to be meant with the hapax $\varkappa \varepsilon \varphi \alpha \lambda \hat{o} \beta \rho \omega \tau \alpha$, 'eaten away at the top',

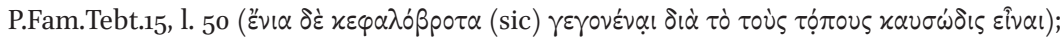
this compound also occurs in l. 92. This type of damage at the top may be due to how papyrus rolls were stored. A now-lost relief from Neumagen shows rolls kept on shelves (armaria) in horizontal position with their tops exposed to the outside (the relief is known only from an engraving in Brower and Masen 1670, 105; cf. Marganne 2015, esp. 336-38, $342-46$ ). Alternatively, containers (capsae, xi $\beta \omega \tau$ o $)$ were used to store papyrus rolls in vertical position. A representation of a capsa with 'emerging' roll tops can be seen in a fresco from the House of the Banker (L. Caecilius Jucundus) in Pompei (before $79 \mathrm{CE}$ ), now at the Museo Archeologico Nazionale of Naples (inv. 4675, image in Braganti and Sampaolo 2013, 384; cf. Longo Auricchio et al. 2014, esp. 392-4).

$38 \quad$ P.Fam.Tebt. 15, lines 68-71 (transl. by the authors). 
In order to remedy this situation, the tasks of Isidorus fall into two parts. First, he is asked to gather together the unattached $(\dot{\alpha} \sigma \dot{v} v \varepsilon \varepsilon \tau \alpha)$ documents into $\tau o ́ \mu o 1 ~ \sigma o \gamma \varkappa 0 \lambda \lambda \eta \dot{\sigma} \sigma \mu \mathrm{o}$. This refers to the standard practice of gluing certain kinds of documents together, generally in chronological or topographical order. ${ }^{39}$ Some of the documents in the archive, it appears, had already undergone this

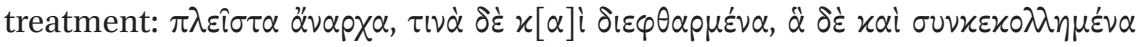
(P.Fam.Tebt. 15, l. 88), 'most without their beginnings, some damaged, some others pasted together'. By its very nature, the practice of gluing together documents testifies to the vulnerability of the beginnings and ends of rolls, where the horizontal fibres were exposed to frequent handling. By pasting a number of documents together in one roll, the most vulnerable parts of the papyrus are reduced drastically from two per document to two for the entire tópos

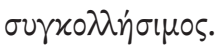

Second, Isidorus is asked to repair and reconstruct damaged documents. The following passages do not allow us to decide without doubt which of the two tasks is referred to. The issue is the use of the verb $\delta 1 \alpha x 0 \lambda \lambda \alpha \omega$, which we have seen before in the quotation from Lucian, and whose corresponding noun $\delta\left\llcorner\alpha \dot{c}^{\prime} \lambda \lambda \eta \sigma \iota \varsigma\right.$ we left untranslated in the passage quoted above. It can be taken to mean 'paste together', but also 'repair'.

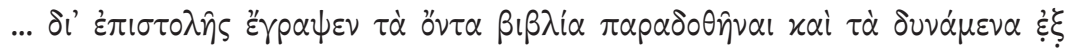
$\alpha \dot{\tau} \tau \hat{\omega} \nu \delta 1 \alpha x 0 \lambda \lambda \eta \theta \hat{\eta} \nu \alpha .^{40}$

... he wrote in the letter to transfer the books that were there, and repair / paste together (?) as many of them as possible.

The context here does not allow us to decide about a translation. We are given a bit more information in the following passage:

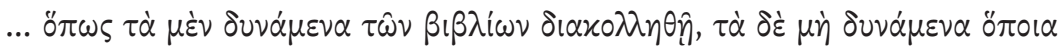

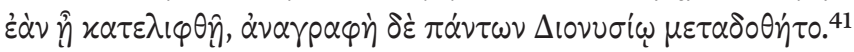

39 See Burkhalter 1990, 195-196, Vandorpe 2009: 243-244, and especially Clarysse 2003, who

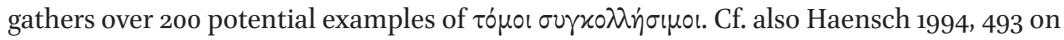

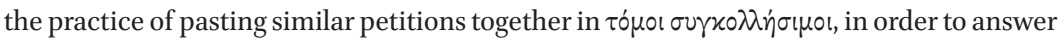
them all with a single subscriptio, saving the clerk the time of having to answer them all individually. P.Bub. 4 gathers the correspondence of a $\delta 10(x \eta \tau$ ' 5 on multiple topics from the year 221 CE in a single roll. Mitteis and Wilcken 1912, vol. II Chrest. 183, ll. 18-19 men-

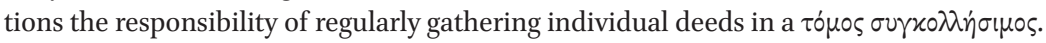

$40 \quad$ P.Fam.Tebt. 15, 1l. 54-55 (transl. by the authors).

41 P.Fam.Tebt. 15, ll. 103-104 (transl. by the authors). 
... so that those books that are repaired / pasted together (?), and those that cannot are left behind in whatever state they are in, and that a list of all of them be given over to Dionysius.

The apparent mention of 'documents beyond repair' here suggests that the other documents are adduced here as still meriting repair, but the sentence may still mean 'those documents that are intact enough to be pasted together'. If we consider again the passage from Lucian, it seems clear that the bibliophile is unlikely to be interested in pasting together documents. More likely

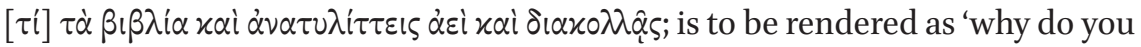
insist on re-rolling and repairing / reinforcing' old or damaged bookrolls?

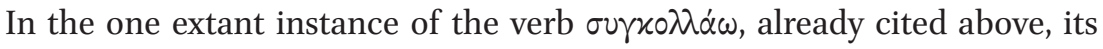

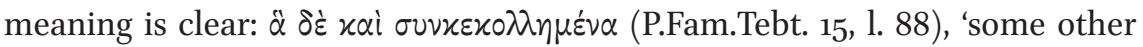

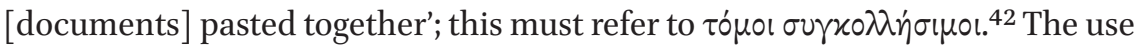
of the noun $\sigma 0 \gamma x \dot{\gamma} \lambda \lambda \eta \sigma \iota \zeta$, however, does not appear to be as restricted. In the

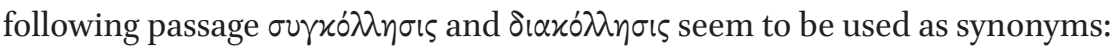

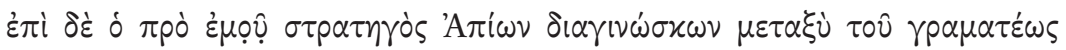

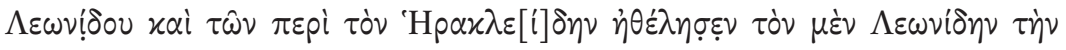

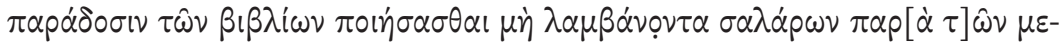

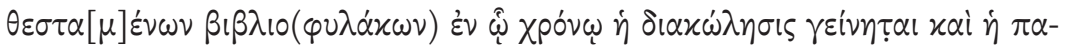

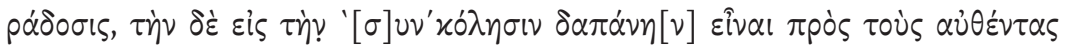
$\beta ı \beta \lambda 10 \varphi v \dot{\lambda} \alpha x \alpha \varsigma^{43}$

But Apion who preceded me as strategus, inquiring into the dispute between the clerk Leonides and Herakleides with his partners, wished that Leonides should make the transfer of the rolls without receiving any salary from the retired keepers for the time necessary for the pasting and the transfer, but that the expenses of the pasting should be chargeable to the responsible keepers.

As regards the difference between the verbal stems $\sigma u \gamma x \circ \lambda \lambda_{-}$and $\delta 1 \alpha x \circ \lambda-$-, we should not disregard the intuitions of Bell and van Groningen. In an article containing notes on P.Fam.Tebt. 15, before its full publication, Bell

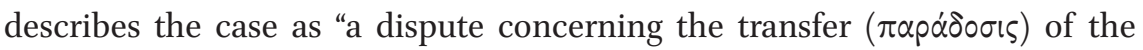

42 In l. 23 van Groningen $195^{\circ}$ prints the supplement $\left.\sigma u \gamma x 0 \lambda \lambda \eta\right] \theta \varepsilon \dot{\varepsilon} \tau \omega \nu$, which is not translated (but recorded in the commentary and in the index).

43 P.Fam.Tebt. 24, ll. 84-88 (transl. van Groningen 1950); cf. P.Berol. inv. 13992 = SB 7404 [duplicate], ll. 41-46. 


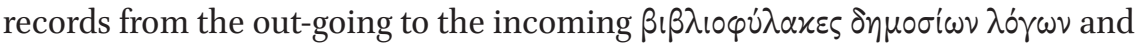

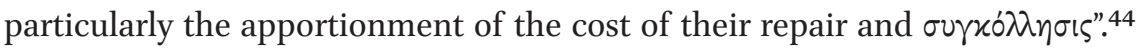

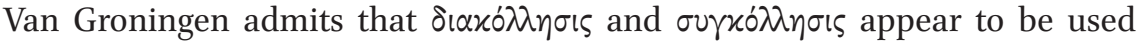
interchangeably: ${ }^{45}$ he translates the two nouns as 'repair' only in two occurrences, ${ }^{46}$ while he always renders the corresponding verbs as 'paste together'. In any case, it is clear from the following passage that repair and reconstruction were definitely part of the necessary overhaul of the archives:

xai है

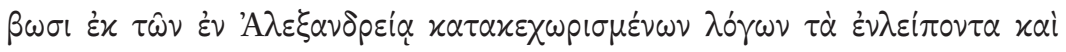

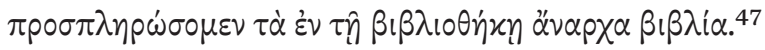

And Mettius wrote to Archelaus, sometime strategos, to make sure that we copied the missing parts from the documents entered at Alexandria and completed those rolls in the archive that are without beginnings.

Due consideration of this invaluable source reveals two things. First, the law case shows that damage to bookrolls and sheets was a known problem, and the issue of missing beginnings is mentioned in particular and repeatedly. Second, it shows that repairing bookrolls where possible was an accepted remedy for such damage. Reinforcement of roll beginnings is not mentioned as far as we can establish, but it is a natural extension of such tasks. In general, it gives a rare if hazy insight into some of the terminology used, and we may conclude

44 Bell 1920, 100-101, cf. 104: "the $\pi \alpha \alpha^{\alpha} \delta 0 \sigma t \varsigma$, which as we learn from the other evidence, included the repair, etc.".

45 Comm. on P.Fam.Tebt. 15, l. 37; see also P.Fam.Tebt. 24, 'Conclusions', p. 108 iv.c.: "The responsible officials ought to be present at the $\pi \alpha \rho \alpha \dot{\delta} 0 \sigma ı \varsigma$ and the $\pi \alpha \rho \dot{\alpha} \lambda \eta \mu \psi \iota \varsigma$; a list $\left(\dot{\alpha} \nu \alpha \gamma \alpha \varphi \eta^{\prime}\right)$ of the transferred rolls must be drawn up, signed by the official and registered in the archive. As far as necessary, the damaged rolls must be repaired before the transfer in the same way as, during the time of office, the keeper in charge must take care of the

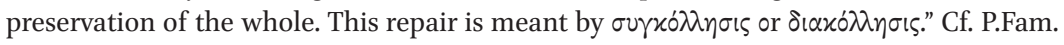
Tebt. 24, p. 98, no. 10: "It is certain that the expression $\tau \dot{\alpha} \delta \nu \nu \alpha \dot{\alpha} \mu \varepsilon \alpha \delta \delta \alpha x \circ \lambda \lambda \eta \theta \hat{\eta} \nu \alpha \iota$ admits of very different applications: the retired keepers will sooner have doubted or denied the possibility of repair than their successors. All this seems to make it clear that the retiring officials must transfer the archives in the best condition possible at their own expenses, but that the successors are bound to accept such rolls as irremediably damaged; in theory this is a very reasonable rule, but in practice it must give rise to constant disputes."

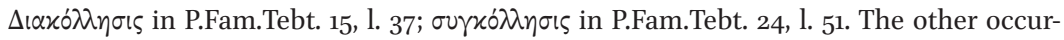
rences in which the two nouns are translated as 'pasting together / pasting' are: P.Fam. Tebt. 15, l. 102, P.Fam.Tebt. 24, l. 87 ( $\left.\delta \iota \alpha x^{\prime} \lambda \lambda \eta \sigma \varsigma\right)$ ) P.Fam.Tebt. 15, l. 20; P.Fam.Tebt. 24, ll. 87,

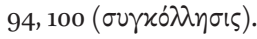

P.Fam.Tebt. 15, 1l. 83-85 (transl. by the authors). 
the following: (1) In P.Fam.Tebt. 15 and 24 there is particular emphasis on the damaged nature of the rolls and the necessity to repair them, not simply to

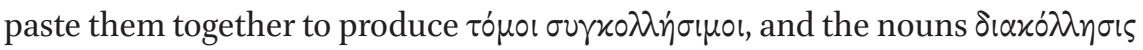

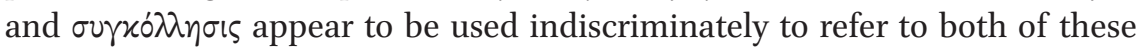

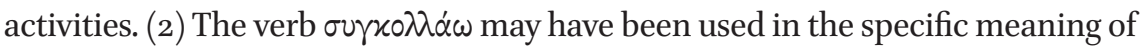

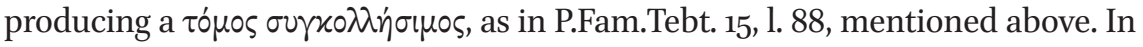
addition, the adjective $\sigma 0 \gamma x \circ \lambda \lambda \dot{\eta} \sigma \mu \circ$ s itself should surely count for something.

The Latin equivalent of $\delta(\alpha x) \lambda \lambda \alpha \omega$ appears to have been glutinare. We come across the word glutinatores in a much-discussed passage in one of Cicero's letters to Atticus. ${ }^{48}$ The word refers to two slave librarians (librarioli) who are meant to help Cicero repair his damaged books (as glutinatores) after returning from exile. Dorandi concludes from the passage that glutinatores must at least have been involved in preparing title tags and restoring damages, but that

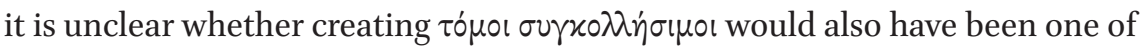
their tasks. ${ }^{49}$

Although P.Fam.Tebt. 15 concerns a public archive rather than a public library, we can posit that the tasks of a slave librarius and a public clerk

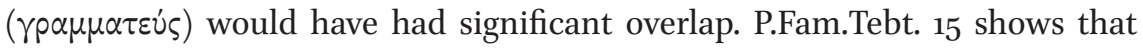
clerks were charged with both pasting together and repairing documents, and it is likely that these tasks would likewise have been within the remit of the slaves requested by Cicero. Puglia could also have made use of P.Fam.Tebt. 15 in his argument that the task of repairing was not generally carried out by a separate specialist, but rather by a librarius. ${ }^{50}$ The documentary text testifies exactly to the fact that it was the clerks' task to keep the documents in good order, and repair them if necessary.

48 Cic. Att. 4.4a: offendes dissignationem Tyrannionis mirificam librorum meorum, quorum reliquiae multo meliores sunt quam putaram. et velim mihi mittas de tuis librariolis duos aliquos quibus Tyrannio utatur glutinatoribus, ad cetera administris, 'You will find that Tyrannio has made a wonderful job of arranging my books. What is left of them is much better than I had expected. And I should be grateful if you would send me a couple of your library clerks to help Tyrannio with the gluing and other operations' (transl. Shackleton Bailey). The only other occurrence of the term is in a fragment of Lucilius (fr. 798 Krenkel) praeterito tepido, glutinator, glutino. The line is adduced for its use of glutino for glutine, and means 'cover it with warm glue, gluer', supposedly with reference to a bookroll or title tag; cf. Dorandi 1982.

49 Dorandi 1983, 28; cf. Puglia 1997, 99-119; Houston 2014, 218-220.

5o Puglia 1997, 101: "Non risulta, d'altra parte, che nello scriptorium di Attico o in altri centri di copia da noi conosciuti vi fossero dei puri e semplici restauratori (glutinatores o comunque li si voglia chiamare) distinti dai librarii". He also adduces a decree in the Codex Theodosianus 14.9.2, which reads antiquarios ad bibliothecae codices componendos vel pro vetustate reparandos quattuor Graecos et tres Latinos scribendi peritos legi iubemus: again, the activities of copying and repairing are undertaken by the same professionals. 


\subsection{Papyrological Evidence}

In papyrological sources, there is ample evidence of repair and reinforcement. Most relevant as parallels for 2288 are the other examples of reinforced roll beginnings. P.Oxy. 2095 is a 2nd-century CE text of Herodotus containing some of the first columns of book 1 of his Histories. On the back, it is reinforced by pasting a papyrus onto it, with the horizontal fibres of the reinforcement glued to the vertical ones of the original. ${ }^{51}$ Just as in the case of our Sappho papyrus, some ink can be seen on an exposed part of the recto of the attached papyrus, at the top of the intercolumnium. ${ }^{52}$ There is also writing on the verso of the added papyrus, whereas none is visible on the back of the Herodotus text. At the top of the verso, another fragment is attached with horizontal fibres facing outward. The papyrus does not allow us to reconstruct whether the entire beginning of the roll was reinforced, or if these are remains of patches to repair some kind of damage. In any case, P.Oxy. 2095 testifies to the vulnerability of the left-hand parts of bookrolls.

P.Oxy. 3369 (3rd century CE) contains the beginning of Menander's Misoumenos, ${ }^{53}$ and was reinforced over its entire height with a sheet of papyrus. The fragment preserves two kollemata with a kollesis running down the middle. It likely contained the very first column of the text, potentially preceded by a title and/or hypothesis in the preceding column. This would make these the first two kollemata, following directly upon the protokollon, if there was one. ${ }^{54}$ Only the left-hand kollema is reinforced, without any trace of a papyrus attached to the back of the kollema to the right of the kollesis. As a consequence, P.Oxy. 3369 offers strong evidence for the reinforcement of specifically the beginnings of rolls. ${ }^{55}$

Among a number of rolls of which only the ends are extant, and which show evidence of reinforcement, P.Oxy. $245^{0}$ is especially relevant. ${ }^{56}$ The 1 st or 2 ndcentury CE manuscript of Pindar's Dithyrambs has pieces of papyrus pasted to the back with the horizontal fibres facing outwards, while others are added

$5^{1} \quad$ Hunt 1927, 136; see also Puglia 1997, 32-33.

52 This is not noted in the ed. pr., but clearly visible on the original.

53 Turner in Chambers et al. 1981; cf. Puglia 1997, 32.

54 See Caroli 2007, 52-55 (with figures) for the beginnings of bookrolls.

55 Cf. Turner 1981, 5: "The explanation for this is probably that this section, being at the beginning of the roll and being subject to much use, was strengthened in antiquity. The sheet pasted on the back is not part of the normal protokollon, since its fibres also ran horizontally, and carried writing."

$5^{6}$ Lobel 1961, 143. Puglia 1997, 36-37 notes that the fragments might come from the end of the roll; D'Alessio 2001, 36 challenges Puglia's methodology, but comes to much the same conclusion. 
with the horizontal fibres against the back of the Pindaric papyrus. ${ }^{57}$ Like in the case of 2288 , we can see traces of the writing on the underlying recto, namely at the height of col. ii, ll. 27 and 28 . There are traces of what looks like

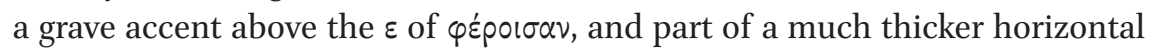
just to the right of that same $\varepsilon$. This papyrus further has in common with 2288 that in most places where the bottom layer is visible, e.g. just below and to the right of this same $\varepsilon$, the uppermost layer of the bottom papyrus appears to have come off. Finally, on the verso, around the same height, there are traces of writ$\operatorname{ing}(\pi$ or $\tau$ ?) on the verso of the Pindaric papyrus-no writing is extant on the verso of the reinforcement.

P.Oxy. 1248 and 1367 are Plato's Politicus on the recto, and the text used to reinforce the tall roll, fragments from Heraclides Lembus' Epitome of a selection of Hermippus' biographies. ${ }^{58}$ The roll was rather tall, at least $32.5 \mathrm{~cm}$ in height, which Grenfell and Hunt believed might have created the need for reinforcement. ${ }^{59}$ In their later publication of the text on the verso, however, they speak of "papyrus rolls which had become worn through ... strengthened with patches gummed on the verso". ${ }^{60}$ At least three separate patches of papyrus can be seen on the verso, with their horizontal fibres facing outward. ${ }^{61}$ One of these is a blank square, another contains the initial or end-title of Lembus' work, and the largest patch, extending almost over the full height of the roll, contains two columns of writing. The writing on both sides is roughly contemporary, so either the text of Lembus' epitome had outlived its usefulness, or it had gotten damaged to such an extent that it could only serve as scrap paper to shore up a stately copy of Plato.

P.Oxy. 5300, a 1st-century CE fragment of Polybius, was repaired with a patch containing remains of Iliad 13, written in a roughly contemporary script: the writing of the patch was facing the back of the Polybius piece (the backs of both fragments are blank; the repair patch has now been removed).

One final example is Dublin Pap. $\mathrm{C}_{3}$, a document from the early 2 nd century CE, re-used on the back for a novel. ${ }^{62}$ The recto contains remains of an account, which must have been damaged through use, since it was reinforced

57 Another, well-studied case is P.Oxy. 1790, cf. Puglia 1997, 35-36, and now Prodi 2019.

$5^{8}$ Now kept in the library at St. Andrews under the inventory number Pap PA3304.S2/11; we thank Julie Greenhill for providing us with digital images of the papyrus.

59 Grenfell and Hunt 1914, 129.

6o Grenfell and Hunt 1915, 113 .

61 Between the patches, especially in the top middle, extensive offsets of the Platonic text can be seen; they remain undiscussed by the editors. For a similar case of offsets produced while a scroll is rolled up, cf. D'Alessio 2009, 37 on the Artemidorus papyrus.

62 First published in Mahaffy 1897 (verso); see Stephens 1989 for the recto. 
in one corner. The patch, recycled from a neat copy of Demosthenes, was probably applied when the roll was being prepared for re-use. ${ }^{63}$

Repairs of papyri can take different forms, but they differ from reinforcements to the extent that parts of the existing roll have to be replaced, including its original writing. With the discussion of P.Fam.Tebt. 15 and 24 in mind, consider the documentary papyrus P.Erbstreit 1, a bank receipt dated to 186 BC that was restored five decades after its issue, when it became relevant for a trial concerning an inheritance dispute. ${ }^{64}$ On the restored parts the missing letters have been added by another hand, possibly the hand also responsible for P.Erbstreit 13 or the hand responsible for 14, 15, and 16 (14 being a copy of P.Erbstreit 1). ${ }^{65}$

Among literary papyri, the finds in Herculaneum form a particularly richif complicated-data set for the ancient conservation of papyrus rolls. By way of example, we may point to P.Herc. $1420+1056$, a 2nd or 1st-century вСE roll of book 25 of Epicurus' On Nature. ${ }^{66}$ The remains of the papyrus show that the final $130 \mathrm{~cm}$ of the roll were replaced, and written by a second hand. ${ }^{67}$

There is also evidence from Egypt, such as PSI Od. 5, a papyrus roll containing the end of Odyssey book $4{ }^{68}$ The final column of the roll is written in a different hand, to be dated later than the rest of the roll. ${ }^{69}$ It is worth pointing out that after the repair the entire text was corrected by the same hand. It seems that, once the end of the roll had been damaged or had deteriorated through age, the final kollemata were removed, and one and a half kollema of a slightly different size were attached. ${ }^{70}$

P.Lond.Lit. 27 is a peculiar case. ${ }^{71}$ The roll contains on its recto books 23 and 24 of the Iliad, repaired roughly in the middle with a kollema replaced right after the end of book 23. The final letters of the final column of 23 have been

63 Stephens 1989, 271.

64 Edited by Vandorpe and Vleeming 2017; see p. 4 for the mention of the repair. We thank Marius Gerhardt for bringing this papyrus to our attention.

65 Vandorpe and Vleeming 2017, 43.

66 Laursen 1987.

67 Cavallo 1984, 7; cf. Puglia 1997, 41. Another example is the apparent insertion of a long stretch (at least $170 \mathrm{~cm}$ ) of papyrus to replace a damaged part of P.Herc. 176; cf. Del Mastro 2010, 47-53.

68 Cf. Turner 1983; Puglia 1997, 39-40; Cavallo 1980; Schironi 2010, 126-127; Ciampi 2016.

69 Cavallo 1980,342 believes the difference between the hands to be a century or more, whereas the original editors say (p. 2o) "le due scritture, pur molto diverse tra loro, non sembrano lontane nel tempo".

70 For the reconstruction, see Cavallo 1980, 340; cf. Ciampi 2016, 195.

71 Also catalogued as P.Lond. 128, published in Kenyon 1891, and further discussed in Kenyon 1893; cf. Puglia 1997, 38-39 and Schironi 2010, 108-109. 
retraced, and the first column of book 24 was written by a rather rough second hand. This second hand is also responsible for corrections throughout the text, and may be "considerably later" (so Kenyon) than the original hand, which is to be dated to the start of the common era. ${ }^{72}$ The fact that the corrector of the manuscript and the scribe of the inserted column are the same shows that it must have been to an extent a professional scribe, even if his text is of a low quality. ${ }^{73}$ Especially considering the fact that he did not have the most accomplished hand, it may be that this very scribe was also the person who undertook the physical repair of the roll. This would reinforce Puglia's belief that scribe and gluer would typically have been the same person. ${ }^{74}$ Finally, it is not impossible that there were originally two rolls, written by the same hand, whose beginning and end got damaged, and which were subsequently pasted together to save having to repair both the end of one roll and the beginning of the next. ${ }^{75}$

Similar, if not quite the same, is the case of P.Mil.Vogl. 205. The papyrus takes the form of a sheet containing on the recto remains of a 2nd-century CE document, and on the verso one column of the second book of Thucydides' Histories..$^{76}$ The piece is almost perfectly rectangular, apparently cut so that it could hold exactly one column of writing on the verso. This hypothesis is supported by the fact that the final two lines are squeezed closely together, even though sufficient space is left in the lower margin. It seems that the scribe was attempting to fit a pre-determined amount of text into one column of a predetermined size. The first editor therefore hypothesised that this sheet was used to repair a roll of Thucydides' second book, pasted onto a damaged column of writing. ${ }^{77}$ In fact, there appear to be traces of glue left on the original recto of the sheet. ${ }^{78}$ If this is right, the sheet will have functioned as a patch on the recto, probably to cover a hole or a tear, rather than replacing a damaged kollema.

\section{5}

\section{Conclusions}

It has become clear that papyrus rolls were damaged through use, and that attempts at conserving them were made throughout antiquity. Especially literary

\footnotetext{
72 Kenyon 1893, 297 dates it to the 1st century вCE, while Cavallo 2005, 118 prefers the first half of the ist century CE.

73 Kenyon 1893, 296, "... this part of the text is full of blunders and practically valueless".

74 Puglia 1997, 101, see above.

75 A possibility allowed, but regarded as unlikely, by Lameere 1960, 169 .

76 First published in Bartoletti 1960.

77 Bartoletti 1960, 65-66; cf. Puglia 1997, 37-38.

78 See section $3(v)$ above.
} 
rolls could be in use over multiple centuries, inevitably necessitating reinforcements or repairs. Some of the strips used to reinforce the 1st or 2nd-century copy of Pindar discussed above, for example, bear cursive script likely to date to around 200 years later. ${ }^{79}$ In the case of 2288 , a second layer of papyrus is visible beneath the fragment containing Sappho fr. 1 . The analysis presented above has convinced us that B is not more of the Sappho papyrus, so it must have been a second papyrus pasted onto its back. Since there is no evidence of the second layer replacing parts of the original papyrus, at least as far as we can tell from what remains, the situation should perhaps be described as a reinforcement rather than a repair.

Exactly because Sappho fr. 1 is such a famous poem, one might consider the possibility that 2288 is not a fragment from Sappho book 1, but rather from an anthology, or even of a single sheet containing only the Ode to Aphrodite. ${ }^{80}$ However, there is another papyrus in the Oxyrhynchus collection written in the same hand as 2288, containing the end of Sappho book 2, complete with end title. ${ }^{81} \mathrm{~A}$ further papyrus in the collection contains an edition of Plato's Phaedo, again by the same scribe. ${ }^{82}$ Both the other Sappho and the Plato have cursive annotations, possibly by the scribe who wrote the literary text. ${ }^{83}$ If more of 2288 were extant, we may well have found comments in its margins, too. In any case, we are justified in believing that this scribe produced a complete roll of Sappho book 1.

Although Turner and Obbink both allow for the possibility that another poem preceded fr. 1 in 2288, their arguments have become void if we accept that $B$ is not in fact more of the same roll. ${ }^{84}$ The other available evidence suggests that the poem stood first in Sappho's first book, which would normally entail that 2288 formed part of the first kollema of a bookroll. Sappho's poetry would have been regarded as valuable and the roll may well have been in use for a long period of time, just like the Pindar of P.Oxy. 2450, necessitating a repair of the roll's beginning. We may remember that P.Oxy. 3369, likewise, has a reinforcement over the entire height of the first kollema. In short, 2288 appears

79 P.Oxy. 2450; the dating of both hands is that of Lobel 1961, 141-143.

8o A number of poems on single sheets are extant, but we know of no cases involving canonical poets: P.Oxy. 1015, an encomium to the gymnasiarch Theon and/or Hermes on a "well-preserved sheet of papyrus", and PSI 1482, two drafts of a hymn to Eirene written on both sides; P.Ryl. Gr. 17 is a reinforced sheet of papyrus containing a short hexameter epithalamium on one side (verso blank); P.Oxy. 3536 has hexameters on glass-blowing written against the fibres on two sheets of papyrus stuck together with traces of documentary writing.

81 P.Oxy. 2076; Lobel identified them as by the same scribe in the edition of 2288.

82 P.Oxy. 1809; on the scribe, see Johnson 2004, 21.

83 So Hunt 1927, 27; Johnson 2004, 21 is doubtful.

84 Turner 1973, 25 and, more tentatively, Obbink 2011, 35-36. 
to be what remains of an edition of Sappho book 1, much used and therefore reinforced at its beginning with another layer of papyrus. ${ }^{85}$

\section{Acknowledgements}

This project was made possible by a Veni grant funded by the Netherlands Organisation for Scientific Research (NWO), project number 275-30-038. For extensive access to P.Oxy. 2288 and use of the images we thank the Egypt Exploration Society and The Oxyrhynchus Papyri Project. We thank Prof. Patrick Grant, Guy Tolley, and Oxford Materials Characterisation Service for the access to equipment and their generous assistance. Finally, we thank the anonymous reviewers for their comments and suggestions.

\section{Bibliography}

Bartoletti, V. (1960). Tucidide II 73,1-74,1 in un papiro dell'Università Statale di Milano. In: AA.VV., Studi in onore di L. Castiglioni, Milan, pp. 59-66.

Bastianini, G. (2009). Sull'avvolgimente del rotolo di Artemidoro. APF 55, pp. 215-221. Bell, H.I. (1920). Notes from Papyri in the British Museum. APF 6, pp. 100-101.

Braganti, I., and Sampaolo, V., eds. (2013). La pittura pompeiana. Naples.

Burkhalter, F. (1990). Archives locales et archives centrales en Égypte romaine. Chiron 20, pp. 191-216.

Caroli, M. (2007). Il titolo iniziale nel rotolo librario greco-egizio. Bari.

Cavallo, G. (1980). Angolo di scrittura. $S \& C$ 4, pp. 337-344.

Cavallo, G. (1984). I rotoli di Ercolano come prodotti scritti. Quattro riflessioni. Scrittura e Civiltà 8, pp. 5-30.

Cavallo, G. (1986). Conservazione e perdita dei testi greci. In: A. Giardina, ed., Società romana e impero tardoantico, Vol. 4: Tradizione dei classici, trasformazioni della cultura, Bari, pp. 83-172.

Cavallo, G. (2005). Il calamo e il papiro. La scrittura greca dall'età ellenistica ai primi secoli di Bisanzio. Florence.

85 The survival of the beginning of the roll only may seem surprising, but it could simply be an accident of conservation. We may consider the possibility that this piece of the roll survived because it was rolled up in the middle, i.e. that the book was rolled up "in posizione finale di lettura", as D'Alessio suggests. This is further supported by the physical shape and dimensions of the fragment, cf. D'Alessio forthcoming. 
Chambers, M., Cockle, W.E.H., Shelton, J.C., and Turner, E.G., eds. (1981). The Oxyrhynchus Papyri, Vol. 48. London.

Chang, R.-L. (2014). Un dossier fiscal hermopolitain d'époque romaine. Cairo.

Ciampi, A. (2016). Contributo per una rilettura di PSI Od. 5. In: A. Casanova, G. Messeri, and R. Pintaudi, eds., E si d'amici pieno. Omaggio di studiosi italiani a Guido Bastianini, Vol. 1, Florence, pp. 195-198.

Clarysse, W. (2003). Tomoi synkollesimoi. In: M. Brosius, ed., Ancient Archives and Archival Traditions, Oxford, pp. 344-359.

Cuvigny, H. (2009). The Finds of Papyri. The Archaeology of Papyrology. In: R.S. Bagnall, ed., The Oxford Handbook of Papyrology, Oxford, pp. 30-58.

D’Alessio, G.B. (2001). Danni materiali e ricostruzione di rotoli papiracei. Le Elleniche di Ossirinco (POxy 842) e altri esempi. ZPE 134, pp. 23-41.

D'Alessio, G.B. (2009). On the 'Artemidorus' papyrus. ZPE 171, pp. 27-43.

D’Alessio, G.B. (forthcoming). Physical Lay-Out and Reconstruction of Fragmentary Texts. Two Case Studies from Lyric Poetry. In: G.B. D’Alessio, C. Carey, and M. Alexandrou, eds., Song Regained. Working with Greek Poetic Fragments, Berlin.

Del Mastro, G. (2010). Papiri Ercolanesi vergati da più mani. S\&T 8, pp. 3-66.

Dorandi, T. (1982). Lucilio, fr. 798 Krenkel. SIFC 54, pp. 216-218.

Dorandi, T. (1983). Glutinatores. ZPE 50, pp. 25-28.

Flieder, F., and DeLange, E. (2001). Papyrus. The Need For Analysis. In collaboration with A. Duval and M. LeRoy. Restaurator 22, pp. 84-106.

Folkerts, M. (2005). Hero. In: Der Neue Pauly 6, pp. 243-247.

Grenfell, B.P., and Hunt, A.S., eds. (1914). The Oxyrhynchus Papyri, Vol. 10. London.

Grenfell, B.P., and Hunt, A.S., eds. (1915). The Oxyrhynchus Papyri, Vol. 11. London. van Groningen, B.A. (1950). A Family-archive from Tebtunis (P.Fam.Tebt.). Leiden.

Haensch, R. (1994). Die Bearbeitungsweisen von Petitionen in der Provinz Aegyptus. ZPE 100, pp. 487-546.

Houston, G.W. (2014). Inside Roman Libraries. Book Collections and Their Management in Antiquity. Chapel Hill, NC.

Hunt, A.S., ed. (1927). The Oxyrhynchus Papyri, Vol. 12. London.

Johnson, W.A. (2004). Bookrolls and Scribes in Oxyrhynchus. Toronto.

Kenyon, F.G. (1891). Classical Texts from Papyri in the British Museum. London.

Kenyon, F.G. (1893). Brit. Mus. Pap. XCCVIII (IL. XXXIII, XXIV). Journal of Philology 21, pp. 296-343.

Kruse, T. (2002). Der königliche Schreiber und die Gauverwaltung. Untersuchungen zur Verwaltungsgeschichte Ägyptens in der Zeit von Augustus bis Philippus Arabs (3о v. Chr.-245 n. Chr.). Munich.

Lameere, W. (1960). Aperçus de paléographie homérique. Paris.

Laursen, S. (1987). Epicurus, On Nature Book XXV. CErc 17, pp. 77-78.

Leach, B., and Tait, J. (200o). Papyrus. In: P.T. Nicholson and I. Shaw, eds., pp. 227-253. 
Lobel, E., ed. (1951). The Oxyrhynchus Papyri, Vol. 21. London.

Lobel, E., ed. (1961). The Oxyrhynchus Papyri, Vol. 26. London.

Longo Auricchio, F., Indelli, G., Leone, G., and Del Mastro, G. (2014). Immagini degli strumenti scrittori dalle Antichità di Ercolano. In: A. De Vivo and R. Perrelli, eds., Il miglior fabbro. Studi offerti a Giovanni Polara, Amsterdam, pp. 391-424.

Mahaffy, J.P. (1897). Papiro greco inedito. Nota del prof. J.P. Mahaffy presentata dal Socio Lumbroso. Rendiconti della Reale Accademia dei Lincei. Classe di scienze morali, storiche e filologiche 5.6, pp. 91-96.

Marganne, M.-H. (2015). Le relief de Neumagen et les bibliothèques antiques. In: M. De Nonno and M. Capasso, eds., Studi paleografici e papirologici in ricordo di Paolo Radiciotti, Lecce, pp. 333-350.

Mitteis, L., and Wilcken, U. (1912). Grundzüge und Chrestomathie der Papyrusurkunde. (2 vols). Leipzig.

Newman, R., and Serpico, M. (2000). Adhesives and Binders. In: P.T. Nicholson and I. Shaw, eds., pp. 475-494.

Nicholson, P.T., and Shaw, I., eds. (2000). Ancient Egyptian Materials and Technology. Cambridge.

Obbink, D. (2011). Vanishing Conjecture. The Recovery of Lost Books from Aristotle to Eco. In: D. Obbink and R. Rutherford, eds., Culture in Pieces. Essays on Ancient Texts in Honour of Peter Parsons, Oxford, pp. 20-49.

Prodi, E.E. (2019). Polycrates' Guests. Extraneous Text and Ancient Conservation on P.Oxy. 1790. S\&T 17, pp. 1-34.

Puglia, E. (1997). La cura del libro nel mondo antico. Naples.

Schironi, F. (2010). TO MEГA BIB\ION. Book-ends, End-titles, and Coronides in Papyri with Hexametric Poetry. Durham, NC.

Scott, D.A., Dennis, M., Khandekar, N., Keeney, J., Carson, D., and Dodd, L.S. (2003). An Egyptian Cartonnage of the Graeco-Roman Period. Examination and Discoveries. Studies in Conservation 48, pp. 41-56.

Stephens, S.A. (1989). Recycled Demosthenes. ZPE 77, pp. 271-272.

Turner, E.G. (1973). The Papyrologist at Work. Durham, NC.

Turner, E.G. (1983). Sniffing Glue. CErc 13, pp. 7-14.

Turner, E.G., ed. (1981). The Oxyrhynchus Papyri, Vol. 48. London.

Vandorpe, K. (2009). Archives and Dossiers. In: R.S. Bagnall, ed., The Oxford Handbook of Papyrology, Oxford, pp. 216-255.

Vandorpe, K., and Vleeming, S.P., eds. (2017). The Erbstreit Papyri. A Bilingual Dossier from Pathyris of the Second Century BC. Leuven. 